archives-ouvertes

\title{
The Circular Relationship between Inequality, Leverage, and Financial Crises
}

Rémi Bazillier, Jérôme Hericourt

\section{To cite this version:}

Rémi Bazillier, Jérôme Hericourt. The Circular Relationship between Inequality, Leverage, and Financial Crises. 2016. halshs-01251360

\section{HAL Id: halshs-01251360 https://halshs.archives-ouvertes.fr/halshs-01251360}

Preprint submitted on 6 Jan 2016

HAL is a multi-disciplinary open access archive for the deposit and dissemination of scientific research documents, whether they are published or not. The documents may come from teaching and research institutions in France or abroad, or from public or private research centers.
L'archive ouverte pluridisciplinaire HAL, est destinée au dépôt et à la diffusion de documents scientifiques de niveau recherche, publiés ou non, émanant des établissements d'enseignement et de recherche français ou étrangers, des laboratoires publics ou privés. 


\title{
Document de Recherche
}

$n^{\circ}$ 2015-06

\section{«The Circular Relationship between Inequality, Leverage,} and Financial Crisis »

\author{
Rémi BAZILLIER \\ Jérôme HÉRICOURT
}




\title{
The Circular Relationship between Inequality, Leverage, and Financial Crises ${ }^{\nabla}$
}

\author{
Rémi Bazillier ${ }^{*}$ and Jérôme Hericourt
}

\begin{abstract}
In this paper, we put into perspective the recent literature which points to inequality as a possible cause of credit bubbles, by reintegrating it into a more general analysis on the two-way relationship between inequality and finance. We focus more specifically on situations where high inequalities and widespread access to credit coexist, and argue that, even when institutions maintain more or less equal access to finance, there may be a dynamic, positive circular relationship between inequality and financial development. However, if we find robust evidence in the literature of a positive causal impact of inequality on credit, the conclusions concerning the distributional impact of financial development, financial deregulation, and financial crises become less clear. A survey of the empirical literature highlights several issues that must be tackled. First, endogeneity: reverse causality and coincidental factors are major concerns. Second, the choice of consistent measurements for the key variables (both credit and inequality) has strong empirical implications, and must be grounded on relevant theoretical channels. Third, those circular dynamics have substantial policy implications for emerging countries, since an increasing number face a joint increase in inequality and credit.
\end{abstract}

JEL classification: D31, E25, E44, G01

Key words: Finance, Inequality, Causality, Institutions

\section{La relation circulaire entre inégalités, crédit et crises financières}

\section{Résumé}

Nous analysons la littérature récente qui met en avant l'impact possible des inégalités sur les bulles de crédit, en la réintégrant dans une analyse plus générale de la double relation entre inégalités et finance. Nous nous concentrons sur des situations où de fortes inégalités et un large accès au crédit coexistent. Même lorsque les institutions garantissent un accès égalitaire à la finance, il peut exister des relations dynamiques et positives entre inégalités et développement financier. Néanmoins, si la littérature suggère l'existence d'un impact causal et positif des inégalités sur le crédit, les conclusions sur l'impact distributif du développement financier, de la dérégulation financière et des crises financières sont moins claires. Notre revue de la littérature empirique permet de souligner l'importance de différents points. Tout d'abord, l'endogénéité: la causalité inverse et les facteurs coïncidents sont des préoccupations majeures. Deuxièmement, le choix des mesures des variables clefs (crédit et inégalités) a des implications importantes sur les résultats empiriques, et doit donc se baser sur les canaux théoriques pertinents. Troisièmement, ces dynamiques circulaires ont des implications politiques substantielles pour les pays émergents, un nombre croissant d'entre eux faisant face à un accroissement conjoint des inégalités et du crédit.

Classification JEL: D31, E25, E44, G01

Mots clefs: Finance, Inégalités, Causalité, Institutions

\footnotetext{
${ }^{\nabla}$ This paper features an online appendix available on the authors' websites, containing additional discussions and an extended methodological presentation of papers.

* Univ. Orléans, CNRS, LEO, UMR 7322, F45067 Orléans, France. remi.bazillier@univ-orleans.fr

University of Lille, CNRS, LEM, UMR 9221, University of Western Brittany - ICI (EA 2652), and CEPII, jerome.hericourt@univ-lille1.fr
} 


\section{Introduction}

The developments in the financial sphere since the end of the 1970s are often presented as increasing efficiency in the allocation of capital, and therefore economic growth. However, almost coincidental with these developments, financial instability, a phenomenon forgotten since the early 1930s, emerged from oblivion. Financial crises are a recurrent phenomenon in both developed and developing economies, with increasing frequency since the mid-1970s. Beyond its massive and long-lasting real impact, the most recent episode in 2007-2008 is distinct from other occurrences because of its origins: excessive mortgage credit to low-income/low-asset/low credit score households - hence the name of "subprime crisis".

For several years now, academic attention has been paid to the regular rise in both income and wealth inequalities. In this context, Atkinson, Piketty and Saez (see, among many others, Piketty, 2003, 2014; Atkinson, Piketty and Saez, 2011) have made seminal contributions emphasizing the rise in the top $1 \%$ income, and the concentration of wealth over the past 30 years, in developed but also in some emerging economies. Less expected, has been the direct, causal relationship between those rising inequalities, excess leverage of poor households, and the financial crisis increasingly advocated by academic economists at the beginning of 2010. Debate entered the public sphere based on Rajan's (2010) argument that rising income inequality forced low and middle-income households to increase their indebtedness in order to maintain their consumption levels, thus temporarily buffering the impact on GDP growth.

This paper provides an analysis of the recent literature on the links between inequality, ${ }^{1}$ credit, and financial crisis, with a special focus on the situation where high inequalities coexist with widespread access to credit. Claessens and Perotti (2007) provide a substantial overview of cross-country and case evidence on the circular dynamics between finance and inequality, with an implicit focus on developing/emerging countries where access to credit may be unequally distributed because of weak institutions. Weak institutions generate inequality in the sense that insiders (political and economic elites) capture the main benefits of financial development. Despite financial liberalization, access to credit and external financing remains very unequal, and concentrated on small elites. Claessens and Perotti (2007) conclude from their overview, that the quality of institutions is decisive for financial development, to effectively broaden access to finance for the greatest number by increasing oversight and competition and reducing inequality. While this reasoning seems perfectly relevant for emerging

\footnotetext{
${ }^{1}$ In referring to inequality, most authors mean to income inequality. However, we will see that useful distinctions can be made between different sorts of (monetary) inequalities: income inequality, consumption inequality, functional inequality.
} 
and developing countries, we argue in this paper that additional mechanisms may be at work in the case of developed countries (and more generally, countries with institutions maintaining more or less equal access to finance) which may still support a dynamic, positive circular relationship between inequality and financial development. In particular, recent evidence from the literature tends to show that income inequality is mainly uncorrelated with inequality of access in fairly advanced economies. In those countries, there is a strong presumption that excess leverage in the recent crisis stems from credit distributed to low-income households.

This is the main idea advocated by Van Treeck (2014) for example, in an extensive review of the various arguments supporting the idea that rising inequalities caused the 2007-2008 US financial crisis. Van Treeck's starting point is that income inequality started to soar in the United States in the early 1980s and easy credit helped lower and middle income households to keep up with the higher consumption levels of top income households. This contributed to the emergence of a credit bubble which eventually burst and triggered the Great Recession. Supply-sided vs. demand-sided rationalizations of these macroeconomic trends are reviewed in Van Treeck (2014), but the current literature provides no clear quantitative assessments of the contribution of each type of factor to the surge in household indebtedness.

This paper assesses those contributions and takes several steps further. First, we start by emphasizing that it is possible, simultaneously, to have institutions allowing broad credit access and substantial inequality concerning other economic dimensions (income, wealth, consumption...). The conjunction of these phenomena opens the possibility for households with insufficient income to support their living standards by increasing their leverage. In this paper, we review the channels through which inequality triggers leverage, and extend the scope beyond the United States case to other financial crises and other countries with different institutions. Second, in such circumstances, an adverse consequence of wide access to credit may be unhealthy credit booms. In most approaches in development economics, when financial frictions decrease (when there is more equal credit access), people will borrow only to fund productive investment in human or physical capital. We show that this is not systemically the case, and point to an additional risk of financial liberalization to emerging economies: if institutions are efficient at preventing rent capture in the financial sector but are not sufficient to contain economic inequalities, then financial development, at some point could generate some financial instability. Third, we would emphasize that in spite of equal access to finance, financial development may still increase inequality through the distributional impact of both financial sphere extension and financial crisis following excess leverage. 
Each of these three key points is discussed separately in the paper, with as great a focus as possible on case and cross-country studies, in both developed and emerging countries. Concerning our first point related to the linkage between inequality and credit, it is necessary to distinguish how inequality might influence demand for credit (for the abovementioned reasons) and credit supply. Regarding credit supply, a main argument is that the institutional environment, either through financial liberalization (which gave banks the possibility to securitize and trade riskier loans, see Shleifer and Vishny, 2010) or recurring expansionary monetary policy, has provided financial institutions with the incentive to increase loans to riskier individuals (Rajan, 2010; Atkinson and Morelli, 2010). However, the causality is not straightforward since increased inequality and financial deregulation (leading to more credit to riskier borrowers) may be the joint product of the trend over the past 30 years, towards liberalization of economic policies: this would imply a positive correlation between inequality and credit supply but not a causal relationship from the former to the latter.

The second major point relates to the mechanisms through which the increased volume of credit results in excess leverage, which eventually degenerates into financial crisis. The evidence in the academic literature is contradictory, with some authors finding no impact (Bordo and Meissner, 2012), others finding mixed evidence (Atkinson and Morelli, 2010), and yet others supporting a causal relationship (e.g., Perugini et al., 2015). Also, a direct corollary of increased aggregate debt is current account imbalance, providing an alternative test of the role of inequality in creating macroeconomic disequilibrium. The evidence here is more conclusive, both theoretically and empirically (Behringer and Van Treeck, 2013; Belabed et al., 2013; Kumhof et al., 2012). As for the link between (excessive) leverage and financial crisis, this point achieves the greatest consensus in the literature. Recent contributions highlight that financial crises triggered by credit bubbles are no longer confined to developing/emerging countries, and that in developed countries household leverage is a key driver of both boom and bust dynamics. Several papers by Jordà et al. (2011, 2013a, 2013b) provide new empirical evidence in this direction, based on long-time historical data.

The third and final point focuses on the reverse relationship, namely the distributional consequences of finance. Until recently, the conventional academic wisdom (Levine, 2005; Beck et al., 2007) was that the quantitative enlargement of the financial sphere (involving more credit and financial services) would systematically reduce income inequality by allowing more constrained individuals (mostly, the poor) to access external finance. However, this belief is being challenged by studies (e.g., Greenwood and Jovanovic, 1990) that highlight a less linear relationship: depending on the level of overall economic development and the existence of rent-capturing behavior among elites, financial development may also increase overall inequality. In relation to the qualitative aspect of financial 
dynamics, the conclusions are much firmer: most studies find that financial liberalization and deregulation actually increase inequalities, especially in developing countries. Poor institutions favoring rent-capturing behaviors (Claessens and Perotti, 2007), and inability of the financial sector to promote transparency are the main explanations. However, even when those problems of systematic misallocations due to weak institutions do not arise, there remains the possibility that a developed financial sphere produces negative distributional impact, due either to the relative increase in earnings of workers in the financial sector (see Philippon and Resheff, 2012), or due to financial crisis generated by excess leverage. Most studies concur about an increase in both income and functional inequality (i.e., a decrease in the labor share) following a financial crisis (Baldacci et al., 2002; Maarek and Orgiazzi, 2013; Meyer and Sullivan, 2013). In this respect, fiscal consolidation may play a nonnegligible role in this negative distributional impact (see among others, Ball et al., 2013).

The mechanisms potentially underlying the two-way relationship between finance and inequality are summarized in the graphic in Figure 1 (the arrows indicate the direction of potential causality).

To summarize, there is little doubt that there are links between inequality and leverage, and that there is likely to be a mix of direct and indirect causal relations, as well as coincidental factors. The next challenge is to provide sound empirical measures of the relative weight of each of these channels. We point to the importance of tackling seriously the issue of endogeneity. As shown by our framework, reverse causality is very likely, and possible coincident factors must be taken into account. We argue also that the choice of relevant measures of both inequality and credit should be made cautiously. The use of secondary sources for inequality presents inherent risks of imprecision and lack of comparability among countries and over time. The data should be chosen taking account of those possible drawbacks. Furthermore, some aggregates of inequalities may hide some of the dynamics that we should focus on, especially when increases in inequality are driven by changes in the upper tail of the income distribution. We suggest using various indexes of inequalities, reflecting changes at both the top and bottom of the income distribution. We need also to consider whether it is the evolution or the level of inequality that is likely to matter. Theoretical mechanisms and empirical strategies will differ. As far as credit measures are concerned, our framework highlights the need to focus on household leverage. Whenever possible, further disaggregation between different types of credit may help to explain the circular relation between inequality and credit.

Stronger empirical evidence should contribute to the design of appropriate policy reforms for the financial sphere, possibly in the prudential area, since recent events have shown that institutions guaranteeing equal access to finance have not been in a sufficient condition to ensure that financial 
development would reduce inequality effectively, and that inequality would not trigger unhealthy financial expansion. Innovative redistribution policies designed to reduce inequality at its origins could also be considered a way to reduce excess leverage.

The remainder of this paper is organized as follows. Section 2 provides some descriptive evidence pointing to a positive correlation between income inequality and growth of the financial sphere, and proposes several mechanisms linking inequality and both credit supply and demand. Section 3 differentiates the complex linkages between inequality, leverage, and financial crises, starting with the links between inequality and leverage; next a complementary channel via the current account balance is investigated; then evidence is presented concerning the link between leverage and financial crises. Section 4 investigates the possible reverse causations between finance and inequality, discriminating between financial sphere dynamics in "normal times" and in periods of financial crisis. Section 5 concludes and suggests some avenues for future research.

\section{Figure 1: A complex tangle of mechanisms}

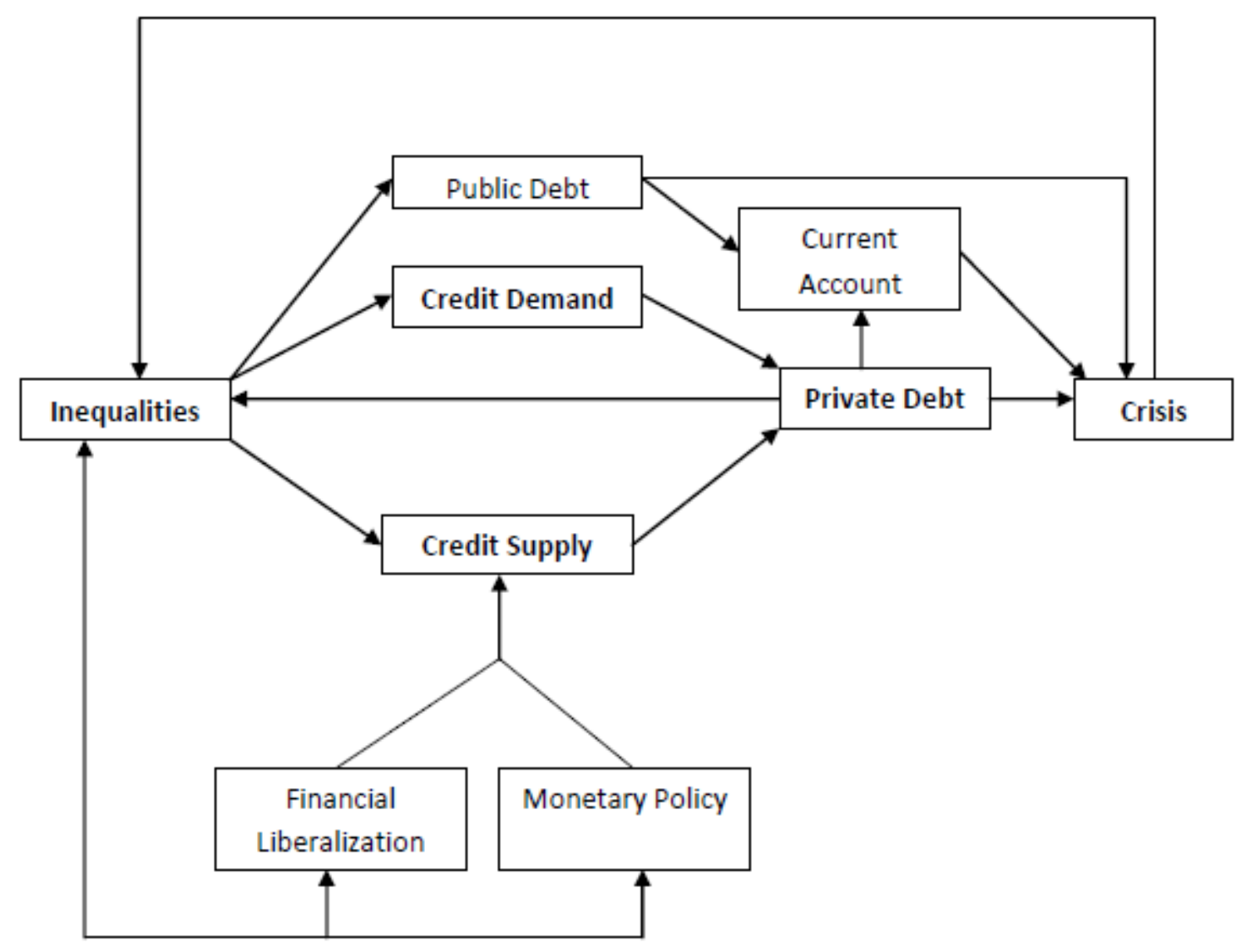




\section{Is there an inequality effect on indebtedness?}

\subsection{Inequality and finance: Some intriguing anecdotal evidence}

Increased private indebtedness raises concerns about both financial instability and the sustainability of current account imbalances. This process has been well documented for the United States (Greenwood and Scharfstein, 2013) where the credit boom is considered a major determinant of the 2007/2008 financial crisis. A similar credit boom has been observed in the case of other countries including a significant number of European countries but also some emerging economies such as China and Korea. Figure 2 represents the evolution of private credit by banks and other financial Institutions (as a percentage of GDP) between 1995 and 2010. In countries such as Spain, the share of credit increased threefold (from $70 \%$ in 1995 to $210 \%$ in 2010).

\section{Figure 2: Private Credit (1995-2010) - Selected countries}
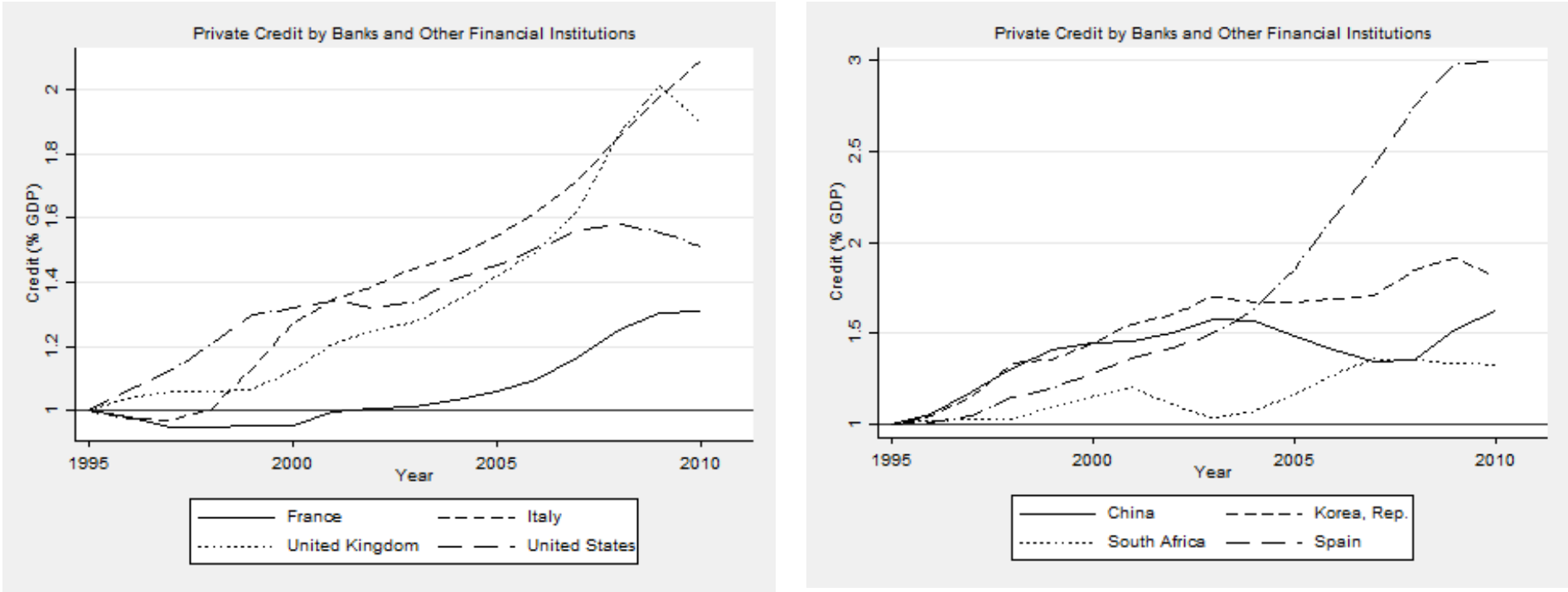

Source: Financial Development and Structure Dataset (Beck et al., 2000, 2009; Cihak et al., 2012), Base 1 in 1995

Meanwhile, there has been a renewed interest in the topic of inequalities. "Bringing income distribution in from the cold"- Atkinson's 1997 presidential address to the Royal Economic Society calls for new research related to income distribution. Since then, several studies have focused on the long-run changes in the distribution of income and wealth. Piketty (2003) and Piketty and Saez (2003) 
respectively document the long-run evolution of inequalities in France and the United States. These works show that the level of inequalities has been relatively stable over the long-run, while the decrease in inequalities observed during the last century was mainly the result of negative shocks due to the two world wars. Piketty and Saez (2006) and Atkinson, Piketty and Saez (2011) show how top incomes dramatically increased from the eighties, mostly in developed, English-speaking countries but also in emerging economies such as India and China. This increasing share of top incomes has been driven by the rise in top wages related to a larger fraction of top incomes than in the past. Figure 3 shows the evolution of the top 1\% income shares in the United States, China, India, Korea, and South Africa. We see a clear breakdown in the downward tendency emerging in the 1980s.

Figure 3: Top 1\% Income Shares, 1950-2012

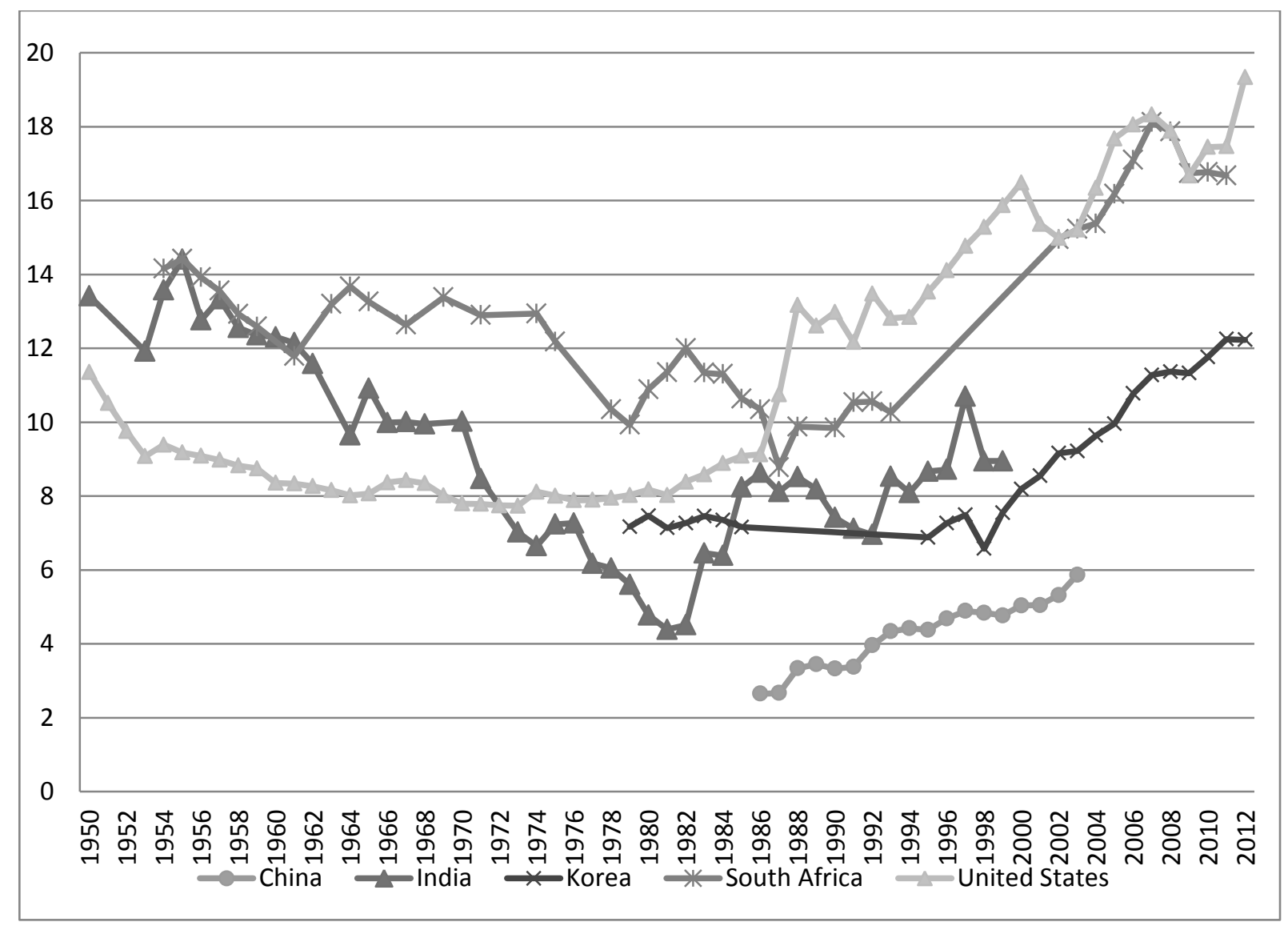

Source: World Top Income Database (Alvaredo et al., 2014)

For illustrative purpose, we describe the evolution in the top percentile of income share and private credit based on the World Top Income Database and the Financial Structure Dataset. The strong correlation between the two dynamics is striking not only for the United States and the United 
Kingdom but also for Continental European countries (such as Spain and also France) and China (see Figure 4). This convergence trend has been particularly strong after 1990 and especially in the period 1995-2000.

Figure 4. Top 1\% Income Share and Private Credit (\% GDP)
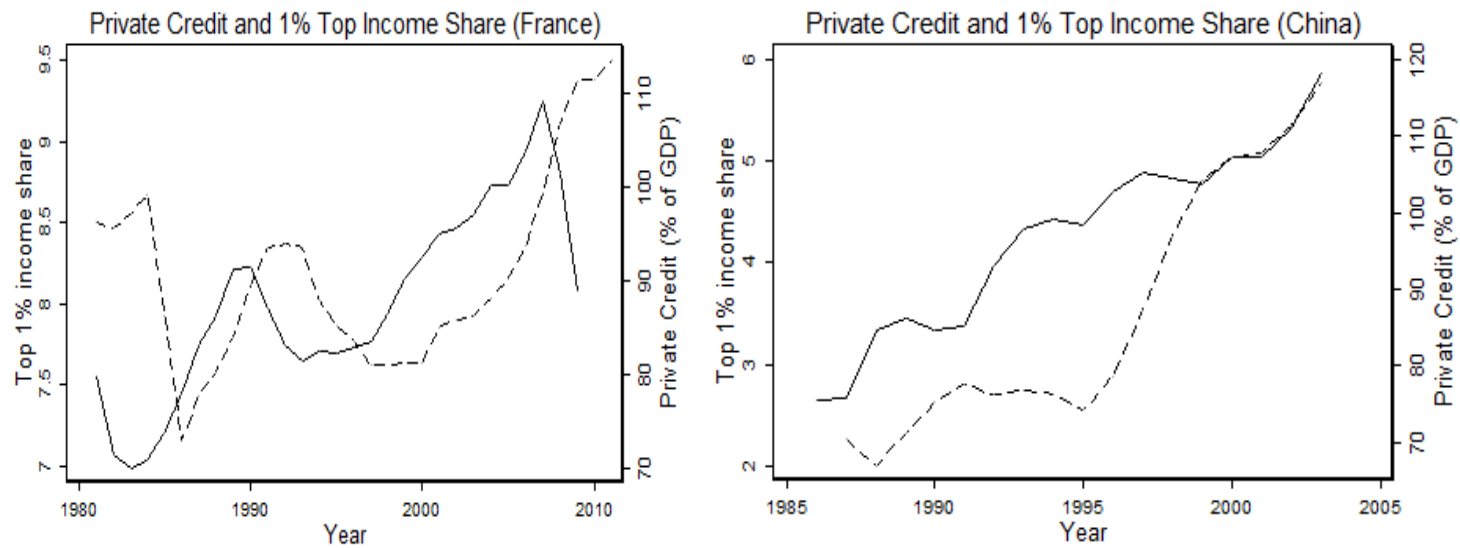

- Top $1 \%$ income share -- - - - Private Credit (\% of GDP)

Source: Financial Development and Structure Dataset \& World Top Income Databas
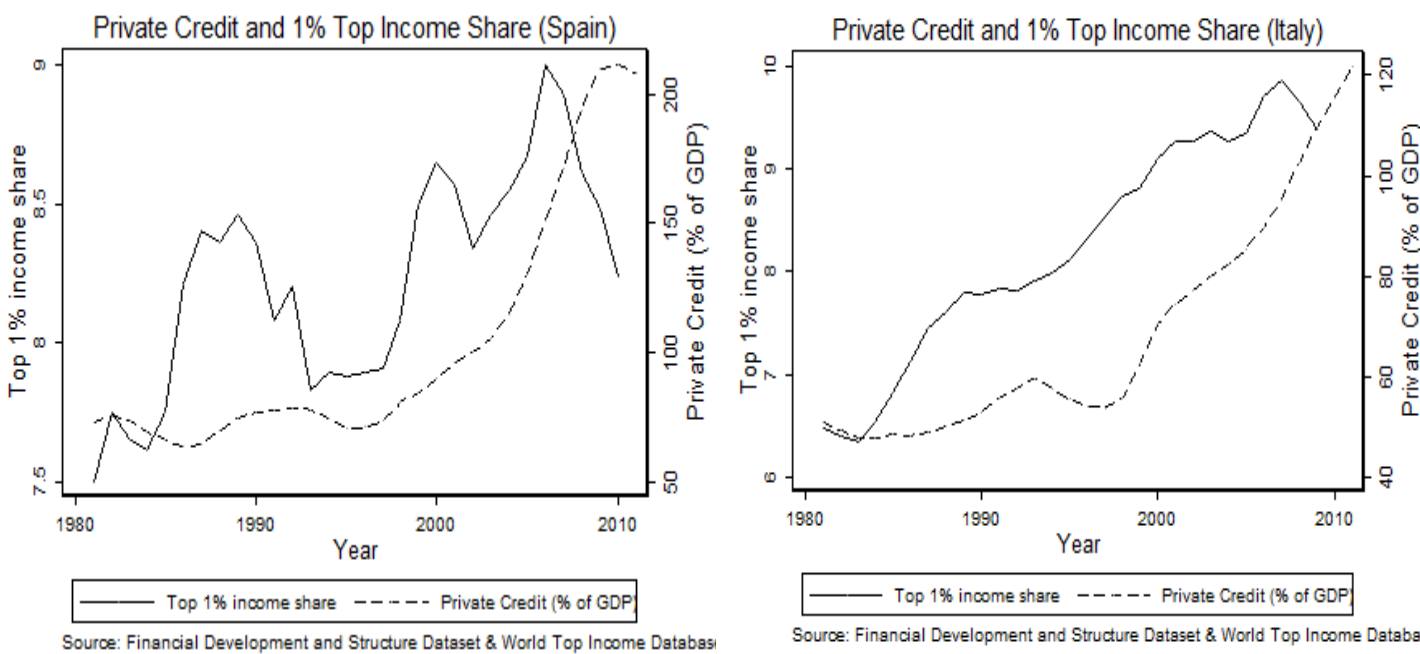

Private Credit and 1\% Top Income Share (United States)

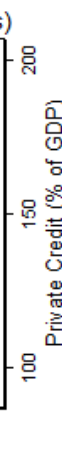

$$
\text { Source: Financial Development and Structure Dataset \& World Top Income Database }
$$

Private Credit and 1\% Top Income Share (United Kingdom)
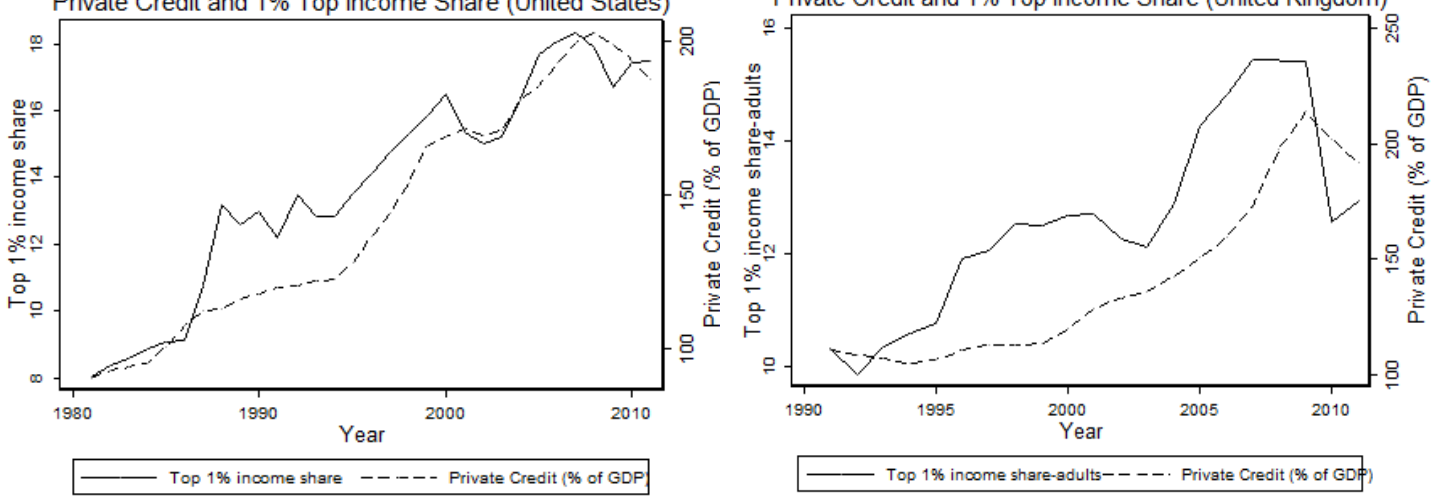
Before studying the consequences of a credit boom for financial instability and financial crisis, we review the main explanations of such booms, focusing on the potential causal impact or coincidental role of inequalities. The literature so far focuses on credit demand and supply channels to explain this leverage. We follow this distinction in the next section, focusing first on explanations of private indebtedness.

\subsection{Credit Demand: the role of inequalities}

Three possible channels inducing a causal impact of inequalities on private indebtedness are commonly studied. The first two relate to consumption behavior, the third reverts to the aggregate demand level. A critical point is that the theoretical mechanisms will be very different depending on whether the rise in inequality is explained by a higher dispersion of transitory income or by a shift of permanent income between social groups. According to permanent income theory, leverage can be seen as a rational answer to a higher dispersion of transitory income. However, if the shift in income is permanent, alternative theories must be mobilized to explain why households decide to increase their borrowing in response to stagnant incomes. First, we review a group of studies showing the impact of a rise in inequalities explained by a higher dispersion of transitory income. We then investigate what might be the consequences of a permanent shift in income.

\subsubsection{Higher dispersion of transitory income?}

The first explanation is based on a higher dispersion of the transitory component of income. Using Italian data, Krueger and Perri (2011) show how credit can be used to smooth consumption in the face of income shocks. Krueger and Perri (2006) find that the increase in income inequalities in the United States, observed over the previous 25 years, was not followed by an increase in consumption inequalities. ${ }^{2}$ They argue that income distribution may not be a good proxy for welfare allocation since a significant share of income variation is transitory and does not affect permanent income. Then, if the volatility of transitory income is increasing (reflecting higher income inequalities in the short run), smoothing consumption through credit may be a rational answer for consumers facing a negative income shock. They develop a theoretical model with endogenous debt constraints to explain these dynamics. Their main result is that the structure of credit markets in an economy is endogenous and may evolve in response to higher income volatility.

\footnotetext{
2 This gap between income and consumption inequalities may have continued to widen during the crisis. In a recent paper, Meyer and Sullivan (2013) show that income inequality in the United States rose by 19\% between 2000 and 2011. In contrast, consumption inequalities increased up to 2005 , then decreased to reach a lower level in 2011 than that observed in 2000 .
} 
Iacoviello (2008) proposes a quantitative dynamic model to replicate the observed simultaneity between the evolution of inequalities and household debt. He explains the rise in debt after 1980 as due to the increased level of income volatility. His model shows that the permanent increase in income volatility after 1980 was the main driver of the credit boom. By focusing on income volatility, the model focuses also on the transitory component of income.

Note that Krueger and Perri's (2006) argument relates only to within-group and not to between-group inequalities. The implicit assumption is that within-group inequalities are more likely to be transitory while between-group inequalities are more likely to reflect a permanent or uninsurable income transfer. If consumers' expectations are correct (particularly regarding the transitory feature of the income shocks they are facing), and if income shocks are indeed transitory, the relation between inequality and leverage may not be a factor in the crisis. The increase in leverage might be a direct response to higher risks (volatility) and better risk-sharing among groups. As Kopczuk et al. (2010, p. 91) suggest, "market economies also generate substantial mobility in earnings over a working lifetime. As a result, annual earnings inequality might substantially exaggerate the extent of true economic disparity among individuals". If this is the case, the consequences of this rise in inequalities will be less severe. Therefore, it is important to understand the dynamics explaining the evolution of inequalities.

Krueger and Perri (2006) find no differences between consumption and income inequalities in the context of between-group inequalities. In order to make the distinction between within- and betweengroup inequalities, they regress income and consumption inequalities on sex, race, years of education, experience, interaction terms for experience and education, dummies for managerial/professional occupation, and region of residence. The cross-sectional variance explained by these characteristics is interpreted as between-group inequality, while the residual variance is seen as within-group inequality.

These assumptions have been challenged by several authors. First, Van Treeck (2014) argues that the distinction made by Krueger and Perri (2006) between within-group inequalities (assumed to be transitory) and between-group inequalities (assumed to be permanent) could be conceptually problematic. He argues that the set of individual characteristics used to define between-group inequality may be too limited, resulting in underestimation of between-group inequality. Second, Kopczuk et al. (2010) show that income mobility decreased slightly since the 1950s in the United States. This result contradicts the hypothesis that the rise in inequalities can be explained by higher income mobility and volatility. Moffitt and Gottschalk $(2002,2011)$ also find that the variance in 
transitory income declined or remained constant after 1980 unlike the variance in permanent income (see also Sablehaus and Song, 2009).

Piketty and Saez (2013) argue that if households perceive an income shock to be permanent, they will adjust their consumption accordingly and no changes in liabilities or assets will be observed. However, if the increased inequalities are explained by a permanent income shock and not by an increase of income mobility, this means that the growing gap between income inequality and consumption inequality may have led to unsustainable increases in leverage. Therefore, we need to understand why households did not adjust their consumption accordingly.

\subsubsection{Consequences of a permanent income shift: "Keeping-up with the Joneses" and the level of aggregate demand}

Piketty and Saez (2013, p. 473) emphasize the massive income shift observed in the United States since the early 1980s: "the bottom 90 percent has become poorer, the top 10 percent has become richer, with an income transfer over 15 percent of US national income. This was a permanent income transfer.» If the transfer really was permanent, the only way to explain the increase in leverage in the permanent consumption theory framework, is that households either did not immediately perceive the income shock to be permanent (i.e., they made errors of expectations), or tried to resist it. Bertrand and Morse (2013) argue that households may not completely adjust their consumption to their income if the welfare loss induced by such a consumption cut is too large in the short run. Piketty and Saez (2013) show that if the bottom $90 \%$ cut consumption levels by half of the negative income shock they face (7.5\% of GDP as opposed to 15\%), this will be sufficient to explain an increase equivalent to $75 \%$ of household debt, which is roughly what was observed.

Since Veblen (1899), it has been well-known that the overall level of satisfaction derived from a given level of consumption depends not only on the actual current consumption level but also on how it compares with some benchmark levels: past consumption of some outside reference group ("keeping up with the Joneses"), or the individual's own past consumption levels ("habit-formation").

The relative income hypothesis is based on similar arguments. This theory proposed initially by Duesenberry (1949), suggests that household consumption is a function of the household's position in the income distribution, and its past levels of consumptions. Van Treeck (2014) argues that this is one of the main explanations for the relatively high consumption path of lower and middle-class households despite stagnation of their income. 
Frank et al. (2014) propose a theory of "expenditure cascade" which is in line with the relative income theory hypothesis. Here the rise in top incomes may have a direct impact on the consumption of the poorest households through this "expenditure cascade". More precisely, "Changes in one group's spending shift the frame of reference that defines consumption standards for others just below them on the income scale, giving rise to expenditure cascades" (Frank et al., 2014, p. 55). The driving force is the income boom experienced by the richest, and its consequences on the consumption behaviors of the lowest earners.

These arguments relate closely to the so-called "Stiglitz hypothesis" (referred to by Atkinson and Morelli, 2011). According to Stiglitz (2009), increased leverage is explained by the willingness of the poorest households to maintain their living standards in a context of income stagnation. Here, the driving force is no longer the income boom of the richest but rather comparison with past living standards for households facing a relative worsening of their incomes. A similar argument is proposed by Kumhof et al. (2015), and is consistent with household debt by income level. As these authors note, in 1983, the top 5\% households had a higher level of debt (by 15\%) than the bottom 95\%. In 2007, situation was reversed: the debt-to-income ratio of the bottom $95 \%$ was twice as high as that of the top $5 \%$.

Contrary to the explanation related to the higher level of transitory income, these hypothesis are consistent with empirical studies showing a permanent shift of income from the bottom $95 \%$ to the top $5 \%$. Kumhof et al. (2015) propose a theoretical model relying on inequalities between household groups and not within groups. Workers borrow to "limit their drop in consumption following their loss of income" (Kumhof et al., 2015, p. 3) which in turn leads to financial fragility. In their model, loans reduce budget constraints, and therefore can be used to maximize utility in each period. The consequence is that this also increases the risk of default, leading to a higher level of financial instability.

Another set of theories focuses on the insufficient aggregate level of demand resulting from an increased level of inequalities. Atkinson and Morelli (2011) describe them as the "under-consumption theories". The argument is not new and goes back to both Marx and Galbraith. The former focuses on the "poverty and restricted consumption of the masses" to explain crises (Marx, Capital Vol. III, ch. 30 quoted in Atkinson and Morelli, 2011). The latter identifies the "distribution of income" as the first "weakness" of the United States economy before the 1929 Great Depression (Galbraith, 1954). When income distribution is very unequal, a high level of demand relies on investment and luxury consumption which may not be enough. 
Overall, there seems to be a solid theoretical background to explain how inequalities may have increased leverage through increased demand for credit. In the next section we examine how an increase in the credit supply may have played a role, and the potential relations with growing inequalities.

\subsection{Credit Supply: Correlation or causality? The ambiguous role of the institutional environment}

The literature investigating financial development (Levine, 2005) tends to focus on the size of the financial sector, associating tight financial development with a rise in the credit supply. However, the overall financial dynamics over the past two or three decades do not completely align with this theory. Deregulation and liberalization are the other prominent features of financial systems evolution. Macro prudential policy gave progressively more freedom for banks to operate in financial markets. Securitization allows banks to remove loans from their balance sheets by transforming them into securities traded on financial markets. Shleifer and Vishny (2010) formalize this behavior of banks explicitly, in a model where banks make, securitize, distribute, and trade loans - as alternatives to holding cash. Banks also borrow money, using their security holdings as collateral, and they operate on markets influenced by investor sentiment. Insofar as mortgage and other loans can easily be securitized, and insofar as there was huge demand for these securities, banks were incentivized to take on greater risks. On the other hand, the housing bubble triggered subprime loans (easy to securitize) to low-income households: inequality therefore had a magnifying effect on the risk-taking behavior of banks. Here, the distribution of incomes appears to have had a causal impact on credit supply.

Another link that can be identified is explained by the rise in the incomes of the richest. If this leads to a rise in savings for this group, this will also increase the credit supply. This is the mechanism developed in Kumhof et al. (2015). Lysandrou (2011) starts from a similar basis: the rise in global savings enabled a huge accumulation of private wealth, which in turn triggered global excess demand for securities driving up the credit supply. This rising supply of capital needs to be invested, even with riskier borrowers, and eventually, this type of investment is made easier through the introduction of structured credit products. ${ }^{3}$

\footnotetext{
${ }^{3}$ An alternative, political economy approach can be found in Atkinson and Morelli (2010, p. 60): the decrease of welfare incomes in general, and pensions from public-funded schemes in particular, implies loss of income for beneficiaries, and consequently increased inequality. Households respond by saving more in private pension schemes (and by purchasing housing). In turn, private pension schemes need to invest the additional funds, even with an increased risk.
} 
Coibion, Gorodnichenko, Kudlyak, and Mondragon (2014) also favor a supply-side interpretation of debt accumulation patterns during the 2000s. They propose a model where income inequality is used by banks as a signal of the underlying credit risk of the potential borrower. The model predicts that banks will grant more credit to lower-income households in low-inequality regions, than in highinequality areas, because higher levels of inequality imply that households' incomes are a stronger signal of solvency. This key prediction is confirmed by an empirical analysis that exploits data on individual mortgage applications in high- and low-inequality regions in 2001-2011, supporting a supply-side view of the credit bubble.

Another common view is that financial institutions have been encouraged to make loans to riskier individuals, reaching a peak with the development of massive distribution of subprime loans to (sometimes very) low income individuals with a high risk of default. Rajan (2010, p. 43), supports this kind of political economy analysis in stating that "growing income inequality in the United States (...) led to political pressures for more housing credit. This pressure created a serious fault line that distorted lending in the financial sector". Here, the political environment is the vehicle of the causal link between inequality and finance.

This argument differs significantly from those in Krugman (2010), Acemoglu (2011) and Atkinson and Morelli (2010). The empirical association between increasing inequality and the credit boom does not necessarily imply causality. Both phenomena might also be the joint by-products of a general political shift towards a more free-market stance. However, the fact that the empirical association between increasing inequality and a boom in credit does not necessarily imply causality, does not need either to contradict the various approaches referred to earlier: it simply means that it is unlikely that there is one single story that explains the joint rise in inequality and credit.

In addition to financial dynamics, a second key aspect of the institutional environment relates to the potential part played by monetary policy. Most analyses focus on demonstrating the existence of a causal relationship from monetary policy to inequality. The relationship between the total volume of credit distributed and inequality may (as we showed in the case of financial dynamics) be analyzed as

\footnotetext{
${ }^{4}$ Coibion et al. (2014) reject explicitly a demand-side explanation of the credit bubble, i.e. that low-income households increased their demand for credit to finance higher consumption expenditures in order to "keep up" with higher income households. In their view, the impact of local inequality on household indebtedness is the most relevant metric for "keeping up with the Joneses". They find that low-income households in high-inequality regions borrowed relatively less than similar households in low-inequality regions. However, they do find a significant impact of the level of income on debt accumulation. If the poorest tend to borrow more, an overall identical increase in inequality (both in low and high inequality regions), will lead to an increase in debt
} 
the joint product of monetary policy actions, i.e. as a correlation with no a priori independent causal relationship going from one to the other.

Based on micro-level data, Coibion, Gorodnichenko, Kueng, and Silvia (2012) assess the effects of monetary policy shocks on consumption and income inequality in the United States. Contractionary monetary policy shocks appear to have significant long-run effects on inequality, leading to higher levels of income, labor earnings, consumption, and total expenditure inequalities across households. This contrasts with the results in Romer and Romer (1998) which are based on a large cross-country analysis and show that, over the long-run, the low-inflation, stable environment favored by contractionary monetary policy actions was associated with improved well-being of the poor. Note, however, that Romer and Romer (1998) find opposite results for the short-run: the cyclical boom created by expansionary monetary policy is associated with improved conditions for the poor in the short-run. Thus, it would seem far from straightforward to settle definitively whether the correlation between credit and inequality is positive or negative. However, over the long-run, the research by Coibion, Gorodnichenko, Kueng, and Silvia (2012) would seem to suggest a negative causality: contractionary monetary policy decreases credit supply and increases inequality.

Gorneman, Kuester and Nakajima (2014) find similar results using a Dynamic Stochastic General Equilibrium (DSGE) framework featuring asset market incompleteness, a frictional labor market, and nominal frictions. On the whole, they find substantial distributional effects of both systematic monetary policy and monetary surprises. A key result is that, while households in the top $5 \%$ of the wealth distribution benefit slightly from a contractionary monetary policy shock, the bottom $5 \%$ suffer a permanent loss to life-time consumption. Once again, this result seems to suggest a negative correlation between credit and inequality. However, Gorneman, Kuester and Nakajima (2014) suggest that a permanent accommodating monetary policy may also increase inequality by dampening economic fluctuations. and consequently, decreasing the need for precautionary savings. The decline in aggregate savings induces a lower capital stock in the economy. This reduces wages, on which the poor in particular rely as a source of income. In that particular context, we may well find a positive correlation between the volume of credit and inequality.

\subsection{Intertwined mechanisms and coincident factors}

It is clear from the above overview of papers that there is nothing to be gained from trying to point to one or other type of explanation (demand or supply-side) for the causal nexus inequality-debt increase. Most papers are based on rigorous theoretical or empirical frameworks delivering evidence in favor of 
both channels. It seems plausible that both are activated simultaneously. This kind of argument is made by Tridico (2012) who sees the finance-led model of growth as a main factor explaining the current crisis. In his view, labor market flexibility and wage moderation have diminished workers' bargaining power which was partly compensated by increased borrowing opportunities due to financial liberalization. According to this view, the policy package which includes both labor market and financial liberalization has two consequences: an increase of the demand for credit due to the fall in workers' bargaining power, and an increase in credit supply explained by financial liberalization.

In this section, we discussed the relations between inequalities and leverage which are numerous but not of all which imply a causal relation from inequality to leverage. The institutional environment (financial development and deregulation, monetary policy) have played a major role in setting a favorable macroeconomic background but this may have only generated additional simultaneous increases in inequality and credit, with no causal link involved. ${ }^{5}$ The causality may also be indirect if growing inequalities push governments and central banks to implement policies aimed at increasing the credit supply. Therefore, the empirical challenge is to disentangle direct and indirect causal relations and possible coincident factors. In the next section, we review papers (mostly empirical) that attempt to address this challenge.

\section{Inequality, Leverage and Financial Crises: Empirical Evidence}

We review the empirical studies focusing on the linkages between inequality, leverage, and financial crises, in three steps. First, we focus on the links between inequality and leverage. Second, we investigate a complementary channel through the current account balance. Finally, we show evidence of a link between leverage and financial crisis. Note that from the outset the effect of the choice of inequality index and database is far from neutral for the results (we refer the reader to online appendix A for a detailed discussion of the measurement of inequality).

\subsection{Inequality and leverage: Contrasting empirical evidence with various interpretations ${ }^{6}$}

Bordo and Meissner (2012) analyze empirically the linkages between income inequality, credit booms and financial crises. Based on a panel of 14 mainly advanced countries for 1920 to 2008, they study

\footnotetext{
${ }^{5}$ However, the sign of the correlation is not clear for monetary policy, essentially because the effect of systematic monetary policy and monetary policy surprises are different.

More methodological details on the papers discussed in this section are presented in section B1 in the online appendix.
} 
the determinants of credit growth using macroeconomic variables and the level of inequality measured by the $1 \%$ top income share. The goal is to see whether the positive correlation observed between credit growth and the top $1 \%$ income share remains valid when controlling for the traditional determinants of credit growth (the business cycle and other macroeconomic aggregates). They first analyze the determinants of credit growth using five year periods, and find that the cumulative change in the log of real GDP is the only significant determinant of credit growth. They also find no significant relation between inequality and credit growth when using the share of the top $0.01 \%$, the top $5 \%$, or the top $10 \%{ }^{7}$

We can identify three major drawbacks to their analysis which call for complementary empirical research on the topic. First, they completely neglect the potential endogeneity between inequality and credit growth and also between credit growth and the other macroeconomic variables. There is a substantial literature on the impact of financial development on inequality (see section 4 below). Therefore, a two-way relationship has to be considered. Second, they focus only on the potential influence of the top income share. In the theoretical analysis proposed by Kumhof et al. (2015), the causal impact of inequality on credit growth has two possible sources: the increase in income of the richest (which increases the supply of credit), and the decrease (or stagnation) in the income of the poorest (which increases the demand for credit). However, Kumhof et al. (2015) do not test the latter possibility. Finally, and probably most important, Bordo and Meissner (2012) consider an overall private credit aggregate, without discriminating between household and firm credit - section 3.3 below emphasizes the criticality of this distinction.

Atkinson and Morelli (2010) study the evolutions of inequality prior to 37 systemic banking crises over the period 1911-2010 (73\% in OECD countries). More precisely, they observe the variations in the distributional variables taking a five-year "window" either side of the crisis date. They find that inequalities increased before the crisis in 10 out of 25 cases that could be identified. In eight cases, they observe no significant change in income distribution before the crisis, and in seven cases, they observe a decrease in inequality prior to the crisis. Thus, the evidence is very mixed and it is difficult to draw firm conclusions about possible causality or the sign of the relation. On the whole, the authors tend towards the most predominant scenario of an inverted U-curve (increasing inequality before the crisis, decreasing inequality after the crisis) applying to 5 out of 25 cases.

Atkinson and Morelli (2010) then compare the situation in countries where a systemic banking crisis was identified in 2007-2008, with countries with no crises. Using the Gini coefficient, they find a

\footnotetext{
${ }^{7}$ Their result is robust to the use of annual data.
} 
similar share of countries where inequalities increased during the 10 years preceding 2007, in the two groups. When focusing on the $1 \%$ top income share, there is slightly higher share of inequalityincreasing countries in the group that experienced a systematic banking crisis in 2007. In their conclusion, they emphasize the potential heterogeneous role of income distribution changes. As already mentioned, it is important therefore, to take a closer look at the potential impact of the whole of the income distribution and not just the top income share.

There are other papers that find more decisive evidence supporting the idea of a causal link between inequality, leverage, and financial crisis. One (Belletini and Delbono, 2013) uses a statistical methodology similar to Atkinson and Morelli; another is closer to Bordo and Meissner (2012) but finds opposite results (Perugini et al., 2015); yet another uses time-series for the United States (Christen and Morgan, 2005).

Belletini and Delbono (2013) check how many countries that experienced a banking crisis were above or below the relevant OECD average inequality level, used as a benchmark. As in Atkinson and Morelli (2010), this analysis is interesting but is not sufficient to claim any causal relationship between inequalities and financial crises since there is no accounting for potential confounding factors. However, based on a sample of banking crises over the period 1980-2010, Belletini and Delbono (2013) find contrasting results to Atkinson and Morelli (2010): they find that a large majority of banking crises was preceded by persistently high levels of GINI coefficients. "9 banking crises out of 14 have been preceded by persistently high levels of high (disposable) income inequality" (Belletini and Delbono, 2013, p. 8). The main reason for this is their focus on the level and not the evolutions of inequalities which is the focus in Atkinson and Morelli (2010).

Perugini et al. (2015) perform an econometric analysis of the determinants of credit growth. Unlike Bordo and Meissner (2012), they find a positive link between income inequality and credit growth. They use a panel of 18 OECD countries over the period 1970-2007. ${ }^{8}$ Two main possibilities might explain these differences. First, they consider the problem of endogeneity and reverse causation. Second, they take explicit account of institutional drivers such as financial deregulation. They also use alternative measures for credit (credit/GDP ratio instead of the log of real bank loans to the private sector) and propose estimating a model in levels rather than variations. Concerning this last choice, the

\footnotetext{
${ }^{8}$ Thus, the time-dimension of their analysis is more limited than Bordo and Meissner (2012). They argue that this is not a major drawback "since it corresponds to the period in which credit started to remarkably decouple from broad money as a result of increased leverage and augmented funding via the non-monetary liabilities of banks. A period in which most developed economies entered an age of unprecedented financial innovation, risk and leverage, which eventually undermined their stability" (Perugini et al., 2013, p. 4).
} 
authors argue that "the literature emphasizes how it is the excessive credit available in the economy that leads to financial crisis. On the contrary, whether higher rates of credit growth lead to a financial crisis or not depends on the initial level of credit available in the economy, since the same growth rate might translate into very different levels of credit and risk" (Perugini et al., 2015, pp. 12-13). To address potential endogeneity, they use Generalized Method of Moment (GMM) estimators (in level and in difference) and both internal (lagged values of the endogenous variables) and external instruments. As external instruments, they use institutional indicators related to labor and product markets, to the rule of law and trade openness. The authors assume that these variables are correlated with both inequalities, investment, and growth but with no direct impact on credit. Overall, they find a positive impact of inequalities on credit, "suggesting that higher inequality directly drives higher credit, once its conventional determinants are controlled for" (Perugini et al., 2015, p. 24). However, the interaction term between inequality and financial deregulation is not significant. The authors do not find that financial deregulation magnifies the effect of income inequality on credit. However, as deregulation is found to have a strong and positive impact on credit growth, they conclude that "the two effects acted separately on credit expansion, without self-reinforcing patterns" (Perugini et al., 2015, p. 25).

Using time-series data, Christen and Morgan (2005, p. 148.) find a "strong positive effect of income inequality on household debt relative to disposable income as well as the components of the household debt (mortgage debt, revolving debt, e.g. credit cards, and non-revolving debts, e.g. car loans)". More precisely, they analyze the determinants of total household debt using quarterly United States data covering all the years from 1980 to 2003 . They find that the income inequality effect is strongest for non-revolving debt and weakest for mortgage debt, but positive in all cases. They argue that this effect is likely to be driven by conspicuous consumption (and therefore a credit demand channel), and has increased over time. ${ }^{9}$ They also try to account for credit supply-side changes by instrumenting the interest rate using an aggregate measure of credit supply. Finally, they estimate the impact of income inequality on car (considered as a conspicuous consumption good) and food (considered as a nonconspicuous consumption good) purchasing. They find a positive correlation between income inequality and car consumptions while the effect on food consumption is not significant. They acknowledge that they cannot provide "direct evidence for a causal link between conspicuous

\footnotetext{
9 Although they acknowledge that their data do not allow them to test this conspicuous consumption hypothesis directly, they show that alternative interpretations do not rule out their main explanations. In particular, they include variables related to life-cycle models (such as the age distribution) as additional controls for the determinants of household debt. Their main results remain valid.
} 
consumption and household indebtedness" but all their estimates are consistent with this interpretation.

To conclude this section, we can say that existing empirical evidence focusing on the link between inequality and leverage is still scarce and the conclusions diverse. We identify several dimensions that might explain this divergence, calling for more research in this area. First, we need to know whether it is the level or the evolution of inequality that matters. The two hypotheses make sense but imply different empirical strategies. Second, we need to properly address the potential problem of endogeneity, i.e., financial development as an obvious effect on inequalities as discussed in section 4. Perugini et al. (2015) propose a means to address this problem but the validity of the external instruments they use (labor and market products regulations, the rule of law, and trade openness) could be challenged. Third, both the use of a given index of inequality and the choice of the database underlying the study are not neutral. Future research should identify whether it is the distribution of income at the top and at the bottom, or the whole distribution of income that matters.

\subsection{Inequality and current account imbalances}

Considering the impact of inequalities on leverage and debt raises a related issue concerning the external equilibrium of the economy. If indeed there is an impact of inequality on overall leverage, we should also expect a modification to aggregate net savings, and therefore to current accounts - this is reflected in the well-known accounting identity: X-M = S-I, i.e., net exports must equal net savings. However, even if we take for granted the impact of inequality on credit and leverage, the effect of the consecutive impact on net savings is not straightforward. All those studies that refer to a credit demand channel (see section 2.2. above) implicitly or explicitly assume that any increase in inequality will lead to a decrease in savings (and more precisely to an increase in borrowing) from the bottom of the income distribution. However, the increase in income of the richest may also increase the level of their savings (allowing a bigger credit supply, as in the Kumhof and Ranciere's, 2015 framework). This may or may not increase sufficiently at the aggregate level to offset the decrease in the net savings (equivalent to an increase in their indebtedness) of the poorest. Therefore, the net effect of inequality on national savings is ambiguous. This ambiguity is confirmed in Schmidt-Hebbel and Serven (2000) and Leigh and Posso (2009) which find no systematic link between inequality and aggregate savings. Therefore, the impact on the external equilibrium is a priori undetermined. In any case, an increasing number of papers has tackled this issue. Figure 6 summarizes the possible linkages between inequalities and current account balance. 


\section{Figure 6: Inequalities and the Current Account}

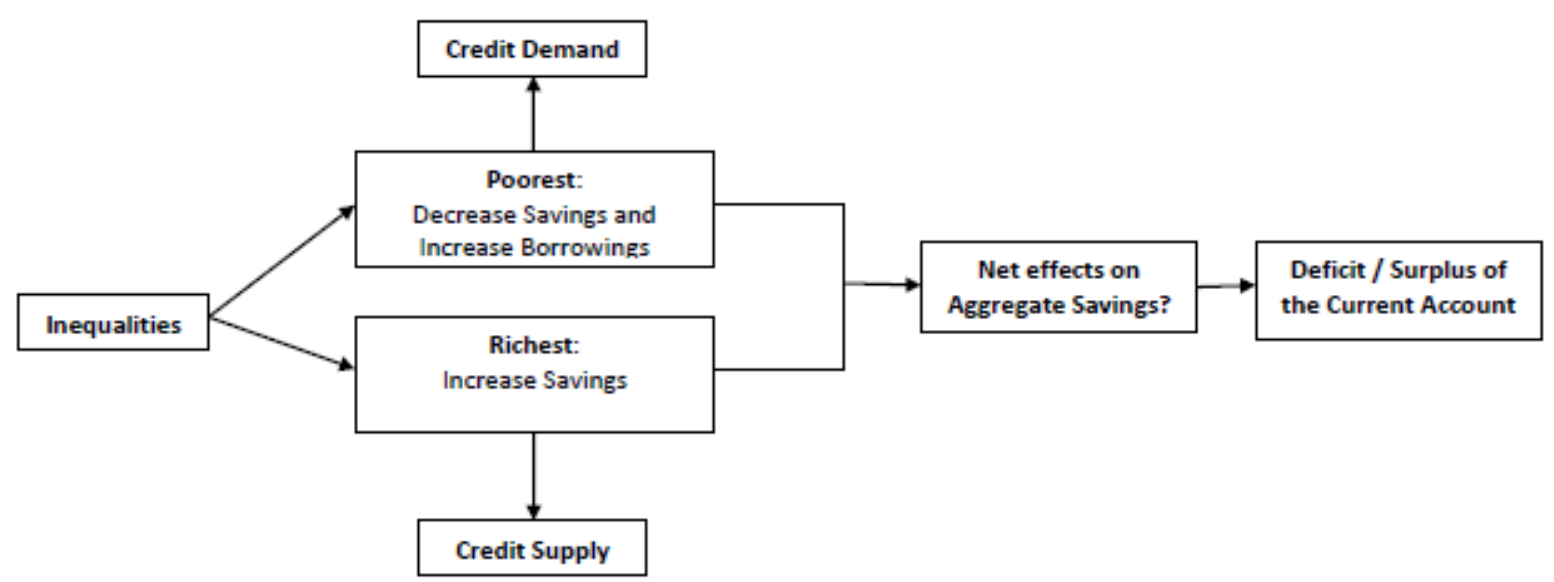

Behringer and van Treeck (2013) propose to analyze this relation for a sample of 20 countries over the period 1982-2007. They make a distinction between personal inequalities (income inequality) and functional inequalities (mainly labor and capital income inequalities). They find that greater inequality is associated with lower household net lending, which has a negative impact on current account balances. They find that the effect is stronger if they consider the top income share than if they use the Gini coefficient. Conversely, increased functional inequalities through declining labor income are associated with higher current account balances (through the corporate financial balance).

There are some recent dynamics consistent with this result. As Behringer and van Treeck argue, the United States and the United Kingdom have faced very strong increases in their top income shares while the shares of labor and capital have remained constant. Both economies have experienced a strong decline in household saving and a strong increase in current account deficits. In contrast, income inequalities in countries such as Germany have not changed fundamentally while their labor shares have declined strongly. According to Behringer and van Treeck, this is consistent with an increase in their current account surplus.

The key element in their analysis is the impact of both personal and functional inequalities on national saving. Behringer and Van Treeck (2013) find a negative impact of income inequality (personal inequality) on aggregate savings. In their view, this result can be explained by expenditure cascade theories (Frank et al., 2014) which explain how the increased consumption of the richest has a trickledown effect on the consumption of the poorest (see also Bertrand and Morse, 2013). This idea is 
supported by their observing a stronger effect for the top income share than for the Gini coefficient. The top of the distribution shapes the consumption behavior of the whole population, explaining the negative impact on aggregate savings. Alvarez-Cadrado and El-Attar (2012) concur with this idea arguing that "individual saving rates decrease with reference income while aggregate saving decreases with income inequality, when households care about their consumption relative to others".

However, for functional (profits vs. wages) inequalities, Behringer and Van Treeck (2013) find the opposite result. Specifically, they find a positive link between the corporate financial balance and the current account. Their main assumption is that household consumption is more sensitive to current income than capital gains. The consequence of that is "aggregate personal saving declines much more strongly when the corporate sector distributes income to rich households in the form of salaries, bonus or dividends, than when it accumulates net financial assets, even if they are ultimately owned by the same households" (Behringer and Van Treeck, 2013, p. 8). Corporate gains are more likely to be saved, thus increasing current accounts.

Along similar lines, Belabed et al. (2013) build a stock-flow macroeconomic model where each country has a household and a non-household (corporate) sector. The household sector is divided into deciles, and characterized by upward-status looking comparisons (in line with the relative income hypothesis and the expenditure cascade described by Frank et al., 2014). Country-specific institutions explain the dynamics of consumption. The model is then calibrated for the United States, Germany, and China. and explains the dynamics of the current account by the worsening of personal inequality in the United States, and by a transfer from households to the corporate sector in Germany and China.

This distinction between personal and functional inequality is not possible in Kumhof et al.'s (2012) theoretical framework since they assimilate the rich with investors and the poor with workers. Thus, the income and functional distributions are equivalent in their framework, following the tradition of Kalecki (1954). They build a DSGE model where investors' income shares increase at the expense of workers. Workers borrow from national and foreign investors to offset the drop in their income share. The model supports aggregate demand but has a negative impact on current accounts. Their interpretation differs from than Behringer and Van Treeck (2013) concerning the heterogeneous

\footnotetext{
${ }^{10}$ Note that the distinction between different types of functional income is ambiguous. The first definition given by the authors is based on a distinction between profits and wages, which is equivalent to a distinction between labor income and capital income. However, they aggregate dividends with other wage income and quote several papers on the corporate veil, studying how investor consumption is affected by the type of returns. For instance, Baker et al. (2007) show that dividends have much stronger effects on consumption than capital gains.
} 
effects of inequality on the current account. In Kumhof et al.'s view, financial market imperfections and the lack of capacity of workers to borrow from investors explain why increased inequalities lead to an improvement in the emerging economies' current accounts. In these countries, only investors have access to financial markets. They deploy their capital abroad (since national workers cannot borrow), leading to a current account surplus. Although this framework is convincing to rationalize current account evolutions in the United Kingdom, the United States, and emerging economies, it is difficult to justify the case of Germany. ${ }^{11}$ Using a panel of 18 OECD countries over the period 19602006, and controlling for the traditional current account determinants, Kumhof et al. (2012) find a negative correlation of -0.1 with the $5 \%$ top income share, and -0.3 with the $1 \%$ top income share. Taking into account the medium-term dynamics, the effect of a $1 \%$ increase in the top $5 \%$ income share is about $-0.25 \% /-0.3 \%$, and the effect of a $1 \%$ increase in the top $1 \%$ income share is about $0.6 \%$. An interesting feature of their empirical analysis is that they include the impact of financial development/financial liberalization, echoing debate on the credit demand versus credit supply channel developed in the previous section of this paper. Kumhof et al. (2012) find that a $1 \%$ increase in the ratio of credit to GDP leads to a 5\% deterioration in the current account. On this basis, they conclude that "if financial liberalization is an endogenous response to an increase in inequality, as Rajan (2010) claims for the United States, estimated coefficients for top income shares may capture part of the effect of financial liberalization" (Kumhof et al., 2012, p. 10). However, they do not quantify the relative importance of this indirect channel. Their theoretical model shows that financial liberalization can be a rational answer to a shift of income from workers to investors since it might finance an increase in aggregate demand. However, it also makes investors direct a larger share of their additional income to financial rather than real investments. It constrains aggregate supply by slowing down capital accumulation, and leads to a higher increase in the rate of return to capital. Because of a higher increase in aggregate demand, and a lower increase in aggregate supply, financial liberalization magnifies the effect of inequalities on the current account.

Al-Hussami and Martin Remesal (2012) find very similar results using a simple current account model with heterogeneous agents. Relative income hypothesis explains why the poorest increase their borrowing after an increase in inequality. As in Kumhof et al. (2012), financial liberalization magnifies the effect because it increases the capacity to borrow. Finally, when Kumhof et al. (2012, p. 1) state that "global current account imbalances were a major source of financial sector fragility in the run-up to the 2007 worldwide financial crisis", they are highlighting that current account is just

\footnotetext{
${ }^{11}$ However, since they consider only the case of income inequalities, and more precisely top income shares, they do not take into account or try to explain the fall in the share of labor observed in Germany. In their view, Germany is part of a group of countries where "no or small increase [of inequalities]" is observed.
} 
the other side of the coin, and are focusing on an issue that is symmetric to the one we examine in the next section, namely the link between leverage and financial crisis.

\subsection{From leverage to financial crisis ${ }^{12}$}

The causal role of excessive private debt in triggering the global financial crisis is long established in the literature, going back to Fisher $(1932,1933)$ and Minsky (1977), and is certainly an idea that has achieved huge consensus. Although some authors point to the role of sovereign debt, ${ }^{13}$ almost all of the recent academic research emphasizes the unstable dynamics resulting from private debt accumulation as the primary trigger of the financial crisis. ${ }^{14}$ In a paper focusing on the euro area, Martin and Philippon (2014) develop a model of open economies within a monetary union where macroeconomic dynamics are driven by private leverage, fiscal policy, interest rate spreads, and foreign demand. Their analysis confirms that household leverage is a key driver of both the boom and bust dynamics. Excess sovereign leverage seems to be the smoking gun only in the case of Greece, where fiscal policy appears the main driver of macroeconomic dynamics.

However, as emphasized by Schularick and Taylor (2012), systematic statistical evidence is scarce and seems focused mainly on emerging countries (McKinnon and Pill, 1997; Kaminsky and Reinhart, 1999; Gourinchas et al., 2001). In the case of developed countries, the idea that systemic financial crises tend to be preceded by rapid credit expansions has been highlighted in relation to both the 2007/2008 crisis (Hume and sentence, 2009; Reinhart and Rogoff, 2009) and the Great Depression (Eichengreen and Mitchener, 2003). However, until very recently, systematic evidence allowing a fine identification of crisis episodes was missing for developed countries. This was rectified by Moritz Schularik and Alan Taylor who originated a consistent research program in collaboration together with Oscar Jordà, and built an original and very long (1870-2008) dataset for 14 developed countries.

\footnotetext{
${ }^{12}$ We refer the reader to section $\mathrm{B} 2$ of the online appendix for a more detailed methodological presentation of the referenced papers.

See the recent arguments in Reinhart and Rogoff (2010). Some papers try to establish a link between the level of inequalities, public debt, and financial crisis. Based on data from 50 countries in 2007, 2009 and 2011, Aizenman and Jinjarak (2012) find a negative correlation between income inequality and tax base, and a positive correlation with sovereign debt. This result is consistent with Milasi (2012), who finds a positive correlation between the top $1 \%$ income share and public deficit, using a panel of 17 OECD countries for 1974 to 2005. Finally, Azzimonti et al. (2014) propose a theoretical model in which public debt responds positively to income inequality because of a link with uninsurable income risk. Inequalities in a country may increase public debt in that country but because of financial integration, it may also affect countries where no rise in inequalities has been observed.

${ }^{14}$ Of course, this does not mean that public debt is exempt from all responsibility: Jordà, Schularick and Taylor (2013b) show that the level of sovereign debt magnifies the negative impact of massive private deleveraging following financial crisis.
} 
Schularick and Taylor (2012) highlight the divergence between monetary aggregates and credit dynamics in the second half of the $20^{\text {th }}$ century, and that recurrent episodes of financial instability have been the consequences more often of credit booms that have gone bust. In Jordà, Schularick and Taylor (2011), the 2007-2008 crisis is identified as one of the five big synchronized global financial crises over the considered sample together with two crises in the $19^{\text {th }}$ century $(1873$, and the early 1890s), 1907, and the Great Depression of 1930-1931. They show that global crises typically are characterized by boom and bust dynamics (as measured by growth and investment) that are stronger than in the case of national crises, low short-term rates compared to real growth rates, and deeper recessions ${ }^{15}$ than in normal times. More important in our case, they find that credit trends are a strong predictor of financial crises, and stronger than external imbalances.

Using a dataset similar to the one used in the work by Jordà, Schularick and Taylor, Bordo and Meissner (2012) find a strong positive relationship between the probability of a banking crisis and real credit growth, with a somewhat lagged effect: their downward benchmark implies that a regular 10\% rise in real bank loans over a five year period leads to $5 \%$ increase in the probability of a banking crisis. Perugini et al. (2015) find very similar results based on a dataset of 18 OECD countries over the period 1970-2007: depending on the specification, a 10\% increase in the ratio of credit to GDP raises the probability of a banking crisis by $3.5 \% / 4.5 \%$.

Based on a panel of 37 developed and emerging countries over the 1990 to 2007 period, Büyükkarabacak and Valev (2010) find that a boom in credit to the private sector as a whole, is associated with subsequent banking crises. However, they also provide evidence that the household component is a driving factor in that effect, whereas firm credit growth does not display such a robust and significant impact. The underlying intuition is that firm debt has a much more significant impact than household debt on long-term income. The result is that growth in household credit is much more likely to raise the debt to GDP ratio over the long-run, and therefore the probability of a banking crisis.

When pointing to the specific importance of household debt, it is tempting to focus mainly on real estate bubbles: for example, the 2007-2008 subprime crisis was rooted directly in the huge amount of bad loans, made to people with low or moderate credit scores to buy homes. However, relying on data for United States counties for 2002-2009, Mian and Sufi (2010) emphasize that short-term finance also

\footnotetext{
${ }^{15}$ This point is developed in Jordà, Schularick and Taylor (2013a), who find that financial crisis recessions are costlier than typical recessions, and that more credit-intensive expansions tend to be followed by deeper recessions and slower recoveries. Mian and Sufi (2010) find similar evidence for the most recent crisis in the United States case : based on cross-sectional data for household credit reliance at the county level, they show that household leverage as of 2006 was a powerful statistical predictor of the severity of the $2007-09$ recession
} 
played a major role in the deepening and the persistence of the 2007-2009 recession. ${ }^{16}$ The first step in the analysis focuses on the timing of the recession, and shows that counties experiencing the largest increases in household leverage in 2002 to 2006 exhibited the sharpest relative decline in durable consumption as soon as the end of 2006 (almost a year before the official start of the recession). The second step shows that counties with households more exposed to short-term credit (proxied by credit card utilization rates in 2006) experienced an acceleration of the recession from the fourth quarter of 2008 through the second quarter of 2009. Household leverage as a whole (i.e., including housing credit and short-term finance) appears a powerful predictor of both the occurrence and the severity of the 2007-2009 recession across United States counties.

Mendoza and Terrones (2008) complete the previous analyses by distinguishing between credit booms in advanced and emerging countries, and by relating macro developments to micro, firm-level measures of leverage and financial constraints. Based on data spanning 1960 to 2006, they use event study methods to identify credit booms - 27 in industrial countries, and 22 in emerging economies. Therefore, unlike Jordà, Schularick and Taylor (2011), they do not discriminate between credit booms simultaneous with big global financial crises, and other credit booms. Mendoza and Terrones (2008) find that credit booms are associated with periods of economic expansion, rising asset prices, real appreciation, and widening external deficits, followed by the opposite dynamics when the credit boom goes bust. Credit booms also are associated with procyclical movements in firm-level indicators of leverage, firm values, and use of external financing. When distinguishing between industrialized and emerging economies, they find that these movements are exacerbated for emerging countries. In particular, they find that credit booms are more likely to end in a financial crisis in emerging countries.

To summarize, a major insight from section 3 is that the type of leverage considered is probably crucial: it seems to be the major predictor of financial crises, and recessions more widely. Failure to examine the specificity of household leverage (compared to total leverage, or firm leverage) may also explain the mixed evidence found regarding the relationship between inequality and leverage. Thus, clarification of this relationship, based on different measures of credit aggregates, would seem a priority for future research.

\footnotetext{
${ }^{16}$ Note that Mian and Sufi's (2010) approach differs slightly from assessment of the impact of the dynamics of credit on the probability of a banking crisis. Their focus is more general in the sense that they study the impact of household leverage on several outcomes, including house prices, new housing building permits, default rates, unemployment, and auto sales.
} 


\section{Measuring the reverse impact of finance on inequality}

A major challenge in the literature that tries to identify a causal link between inequality and financial development is clearly reverse causality. In the following section, we review evidence that both financial development (quantitative and qualitative) and financial crises have strong effects on the distribution of income. It is especially important here to distinguish between the effects of credit growth (size of the financial sector), financial deregulation, and financial crisis, which may show contradictory effects.

\subsection{Financial development, financial deregulation, and inequality}

Why do capital market imperfections have a persistent significant impact on income distribution in the economy? When informational asymmetries and transaction costs are strong, credit constraints are likely to be disproportionately more binding for those such as the poor and small businesses that have no collateral and/or long run relationships with credit suppliers. The development (both quantitative and qualitative) of the financial sector relaxes these credit constraints, and allows more constrained individuals to access external finance. This, in turn, should improve the allocation of capital and alleviate income inequality.

This idea of a linear, positive relationship between financial development and inequality spread quickly in economic research. For example, it underlies Banerjee and Newman's (1993) approach of the interactions between occupational choices and development, and Galor and Zeira's (1993) analysis of individual investment in human capital. In both frameworks, financial market imperfections are mainly binding on the poor, who cannot support the high levels of investment required by entrepreneurial activities or the accumulation of human capital. In both models, the initial distribution of wealth is crucial for determining the ultimate path of the economy: if initial inequality is too high, the economy will become trapped in a bad equilibrium (with low employment and wages in the case of Banerjee and Newman, 1993, and low human capital in the case of Galor and Zeira, 1993). Better access to credit markets, allowing more poor people to become entrepreneurs or to invest in human capital, will help the economy to reach a better equilibrium. ${ }^{17}$ This long-standing conventional wisdom

\footnotetext{
${ }^{17}$ A few papers support more complex relationships. Greenwood and Jovanovic (1990) predict a Kuznets curve (an inverted U, i.e. a hump-shaped relationship) between financial development and inequality. In the early stages of development, both economic growth and savings rates increase but poor individuals save less, and thus accumulate wealth more slowly: income differences between high-income and low-income individuals widens, resulting in an increase in income inequality. At maturity, the economy has developed an extensive structure for financial intermediation, and more agents see their income increase as they gain access to the financial intermediary sector. In the final stage of development, the distribution of income across agents stabilizes, the savings rate falls, and income inequality shrinks.
} 
about financial development and inequality (shared, among many others by Aghion and Bolton, 1992, 1997, and Piketty, 1997) is summarized in Levine (2005, p. 920): "the results indicate that finance exerts a disproportionately large, positive impact on the poor and hence reduces income inequality." Beck, Demirgüç-Kunt and Levine (2007, p. 46) provide a quantitative assessment of this statement: "We found that financial development disproportionately helps the poor.(...) The results indicate that financial development helps the poorest quintile beyond finance's affect on aggregate growth. Indeed, we find that $60 \%$ of the impact of financial development on the poorest quintile works through aggregate growth and about $40 \%$ operates through reductions in income inequality. (...) We also examined changes in the fraction of the population living on less than \$ 1 per day."

\subsubsection{Financial development and the size of the financial sector}

However, the most recent literature tends to question this consensual view, even if the focus is restricted to the extent of available credit and liquidity. It is true that many - mostly empirical - papers support a negative, causal impact on inequality. ${ }^{18}$ Based on standard and Instrumental Variables (IV) estimations for a dataset of 83 developing and developed countries between 1960 and 1995, Clarke et al. (2006) strongly support the notion that financial development (private credit and bank assets) decreases income inequality. Using an almost identical empirical methodology and key variables definitions, Kappel (2010) reaches the same conclusion for a panel of 78 developing and developed countries for the period 1960-2006, as do Enowbi Batuo et al. (2010) based on a dynamic panel estimation for a dataset that includes 22 African countries for the period 1990 to 2004. Mookerjee and Kalipioni (2010) use an original indicator of financial development, namely the number of bank branches per 100,000 populations. ${ }^{19}$ Based on standard and IV cross-sectional regressions for 70 developing and developed countries over the period 2000-2005, they show that greater access to bank branches reduces income inequality across countries.

However, there are some studies that reach less ambiguous conclusions regarding the decreasing impact of financial development on inequality. Law and Tan (2009) rely on a pure time series for Malaysia, using quarterly data for the period 1980-2000, and conclude that financial development is, at best, a very weak and statistically insignificant determinant of income inequality. Arora (2012) uses a sub-national, state-level dataset (discriminating between rural and urban areas) for India, relying on grouped national household sample survey data on monthly household consumption expenditure at

\footnotetext{
${ }^{18}$ For a more detailed presentation of datasets, time period, countries covered, measure of financial development and inequality, etc. in each paper, we refer the reader to online appendix B.3.

${ }^{19}$ In that sense, this definition of financial development may seem close to the idea of financial superstructure in Greenwood and Jovanovic (1990).
} 
sub-national level for the years 1999-2000 to 2006-2007. The results indicate that financial development (proxied mainly by private credit as a proportion of state product) is associated with a reduction in inequality but only in urban areas. Arora finds also that inequality is higher in the richer states compared to less developed and low income states.

Other papers provide additional, cross-sectional or panel evidence of a less straightforward, negative impact of financial development on inequality. Kim and Lin (2011) use an IV threshold regression for a cross-section of up to 65 countries over the period 1960-2005, in order to test the existence of a financial depth threshold such that the effect of financial development on income inequality changes. Financial development is measured using standard liquidity and stock market indicators. Kim and Lin (2011) find that development of both banks and stock markets reduces income inequality if the country has reached a threshold level of financial development. Below this critical value, however, financial development hurts the poor more and exacerbates income inequality. This evidence is consistent with the inverted U-shaped, Kuznets type approach in Greenwood and Jovanovic (1990). Law and Tan (2012) also find evidence of non-linearities in the relationship between financial development and inequality but opposite to those highlighted in Kim and Lin (2011). Based on a dynamic panel data model estimated with GMM for the period 1980-2000, they find that, in the early stages, financial development reduces income inequality but above a certain threshold level, further deepening leads to the reverse effect which deteriorates income inequality. This U-shaped profile is the reverse of that advocated theoretically by Greenwood and Jovanovic (1990), and empirically by Kim and Lin (2011). However, Law and Tan (2012) acknowledge that this result is highly dependent on the selected income inequality dataset. Finally, Jauch and Watzka (2011) perform an empirical analysis based on a very broad dataset (138 developed and developing countries over the period 1960 to 2008), using both standard and IV panel methods. They conclude that financial development increases income inequality although the effect quantitatively is small: an increase in the provision of credit by $10 \%$ leads to an increase in the Gini coefficient of 0.23 for the within estimation. Interestingly, the dataset they use for computing income inequality is the same as the one used by Solt (2009). These same data allowed Law and Tan (2012) to support their result of a U-shaped relationship between finance and inequality. This re-emphasizes that, in addition to the choice of measure of financial development, how income inequality is measured is another important methodological issue (see online appendix A).

This overview of the (quantitative) financial development literature shows great heterogeneity of approaches, with different geographic and time coverage, econometric options, datasets, and treatments for endogeneity. Endogeneity seems particularly crucial in terms of omitted variables which 
may be correlated with both inequality and financial development, and reverse causality between financial development and inequality. More robust IV approaches are needed to achieve strong conclusions about how the size of the financial sector impacts inequality.

\subsubsection{Financial deregulation and inequality}

Another important aspect of financial dynamics is related to important institutional dimensions such as deregulation and liberalization. In theory, financial liberalization and deregulation are implemented simultaneously to increase the volume of available capital and the efficiency of its allocation, and improve access to external finance for credit constrained individuals. However, Claessens and Perotti (2007) review evidence supporting the idea that the quality of institutions plays a decisive part in determining the way financial reforms, designed to increase access to external finance, effectively allow a reduction in inequality. They provide evidence that captured reforms in developing countries deepen rather than broaden access to credit, and produce concentrated benefits, while risks become socialized. Therefore, financial liberalization presented as increasing access, may in practice increase fragility and inequality. The few existing empirical papers support this.

Focusing on the case of India, Ang (2010) discriminates explicitly between the impacts of financial development and financial liberalization on the evolution of income inequality in the period 19512004. Financial development is proxied by standard quantitative variables, and financial liberalization is captured by a synthetic variable provided by Demetriades and Luintel (1996, 1997), based on nine indicators of financial repressionist policies, related to government control of lending and deposit rates, directed credit programs, and a couple of statutory prudential ratios. The study concludes that while financial development can help reduce income inequality, financial liberalization seems to exacerbate it, which, according to the author, is likely due to a rent-capturing attitude among wellconnected elites.

Beck, Levine, and Levkov (2010) assess the impact of bank deregulation (defined as the suppression of restrictions on intrastate branching), in the United States over the period 1976-2006, based on a dataset for 48 States and the District of Columbia. The conclusions are unambiguous: branching deregulation induced a reduction in inequality of personal income of between 3\% and $7 \%$ (10\% when considering the $90^{\text {th }}$ decile $/ 10^{\text {th }}$ decile ratio). This again is consistent with the idea that the quality of institutions is a determinant shaping the sign of the impact of financial deregulation on inequality: it seems sensible to think that United States institutions were sufficiently robust in the 1970s and 1980s, 
when deregulation occurred, to prevent the rent-capturing behaviors that may have been harmful in the Indian case.

Gimet and Lagoarde-Segot (2011) generalize those findings in a cross-country analysis, relying on a set of 49 countries over the 1994-2002 period. Regarding financial variables, several indicators of the size and efficiency of both the banking sector and the capital market are computed, in addition to proxies for financial integration and transaction costs. The main results indicate that increased banking credit and credit market imperfections tend to increase inequalities, while bigger and more efficient capital markets tend to reduce inequalities. Quantitatively, the empirical analysis supports that the banking sector exerts a stronger distributional impact on inequality than capital markets, and that the relationship depends on the characteristics (transparency and ability to allocate resources optimally) of the financial sector more than its size. Again, the qualitative features of financial institutions seem to be crucial for determining in which direction financial liberalization effectively impacts inequality: transparency is key to deterring rent-capturing behaviors, and competition is essential for a good allocation of resources.

Note, however, that again the considered indicator of inequality and the time horizon can substantially affect the results. Philippon and Reshef (2012) study the allocation and compensation of human capital in the United States finance industry over the period 1909-2006. They find a substantial (50\%) wage premium for finance employees after 1990. Also, the 90-10 wage ratio increases from 3.5 in 1970 to 5.15 in 2005 , with finance contributing $6.2 \%$ of the increase. Interestingly, the $97-10$ ratio wage increases from 5 in 1970 to 9 in 2005, with finance this time contributing $15 \%$ of the increase. More generally, Philippon and Reshef's (2012) analysis reveals that finance is responsible for $15 \%$ to $25 \%$ of the overall increase in wage inequality since 1980. The empirical analysis shows that changes in financial regulation are an important determinant of theses evolutions: financial deregulation actually increases income inequality. Those results are completely at odds with those of Beck, Levine and Levkov (2010). The divergence may stem from various methodological differences in these studies (see online appendix B3 for more details on that matter). However, Philippon and Reshef (2012) provide intriguing long-run evidence showing that relative wage inequality was already high at the beginning of the $20^{\text {th }}$ century, before regressing substantially with the re-regulation movement in the period 1940-1985. Philippon and Reshef's (2012) argumentation also draws attention to the fact that this rising wage inequality appears to be one of the determinants of financial sphere expansion, diverting skilled individuals from the rest of the private sector. Finally, the fact that the result is stronger for the 97-10 ratio than for the 90-10 ratio implicitly suggests that the focus should switch to what happens inside the last income decile, rather than focusing on the decile itself. 
Two main lessons can be drawn from this section. First, the effects of financial development (and more specifically, the growth of credit) and financial deregulation on income distribution are not necessarily identical. Financial development has ambiguous effects on inequality, and a non-negligible number of studies find non-linear (sometimes deeply diverging) relationships between the two. The stage of economic development and the quality of institutions preventing rent-capturing behaviors appear the most relevant determinants. The role of institutions seems even more prevalent in the case of financial deregulation, with an influence this time largely disconnected from the overall level of economic development. The second conclusion is that finance has an obvious impact on income distribution, regardless of the dimension we focus on. Therefore, it is absolutely necessary to keep this two-way causality in mind when trying to identify empirically the causal impact of inequality on leverage.

\subsection{The impact of financial crises on inequality ${ }^{20}$}

While financial development and leverage have an impact on income distribution, financial crises have additional and specific effects. The link with the development of the financial sector is obvious. The larger the financial sector, the higher the probability of a financial crisis, all other things being equal. Also, the consequences of financial crises will depend on the size of the financial sector since the larger the financial sector, the more severe will be the crisis. Surprisingly, very few papers focus specifically on the distributional impact of financial crises. It is important to make a distinction between banking crises, currency crises, and combination of the two (twin crises). ${ }^{21}$

The first distributional impact of financial crisis is related to the potential output loss following a crisis. ${ }^{22}$ Like any change in growth level, it will have various (and ambiguous) effects on both income distribution and poverty (Bourguignon, 2004). However, additional; distributional effects may be observed, mainly because of employment problems which are more likely to affect individuals at the

\footnotetext{
${ }^{20}$ More methodological details on the papers referenced in this section can be found in the online appendix, section B4.

${ }^{21}$ A banking crisis is defined as a "financial distress resulting in the erosion of most or all of aggregate banking system capital" (Bordo et al., 2001, p. 55). A currency crisis is more difficult to define. It can be a "forced change in parity, abandonment of a pegged exchange rate, or an international rescue" (Bordo et al., ibid). However, sharp falls in the exchange rate can also be characterized as currency crises. According to Milesi-Ferretti and Razin (2000), a crisis occurs when the nominal depreciation of the currency is at least $25 \%$, which at least doubles the previous year's depreciation, when the latter is below $40 \%$; or when the nominal depreciation of the currency is at least $15 \%$, at least $10 \%$ higher than the previous year's depreciation when this is below 10\%. According to Frankel and Rose (1996), a currency crisis occurs when there is a nominal depreciation of $25 \%$ of the exchange rate. Others use some index of speculative pressure (Berg \& Patillo, 1999; Goldstein et al., 2000; Bordo et al., 2001).

${ }^{22}$ See among others Bordo et al. (2001), Reinhart and Rogoff (2009b), Hutchison and McDill (1999), Hutchison and Noy (2005).
} 
bottom of the income distribution. Especially in developing countries, a financial crisis may lead to job losses in the formal sector, and reduce demand for services in the informal sector. The entry of unemployed formal-sector workers creates pressure on the informal labor market (Baldacci et al., 2002).

In addition to the impact of a slowdown in economic activity, Baldacci et al. (2002) identify three other channels through which financial crises affect poverty and income distribution: relative price changes, fiscal retrenchment, and changes in assets. A devaluation leads to a fall in the earnings of those employed in the non-tradable sector, and increases the demand for exports, therefore leading to an increase in employment and earnings in this sector. The poor may also be affected by the increased price of imported goods, especially food. Since a crisis generally is followed by fiscal retrenchment and public spending cuts, it may affect social assistance outlays, which will amplify the consequences of the crisis for the poor. Lastly, changes in the value of assets have an impact on income distribution since changes in interest rates, and asset and real estate prices are more likely to affect the wealth of the better off.

Baldacci et al. (2002) propose an empirical analysis of the impact of financial crises on poverty and inequality using two types of data. First, they use cross-country macroeconomic data in a quasiexperimental setting, with a special focus on currency crashes. Then, using micro-data, they focus on the Mexican case and the impact of the 1994-1995 currency crisis. Unlike banking crises, currency crises have ambiguous effects on output (Aziz et al., 2000; Milesi-Ferretti and Razin, 2000; Hutchison and Noy, 2002; Gupta et al., 2007), making the study of their distributional impact more difficult. On the whole, Baldacci et al. find a positive impact on poverty headcount ratios and on Gini coefficients. However, the poor in the lowest income quintile are not the most affected; the worst affected are those in the second lowest income quintile. The author argues that this can be explained by the capacity of the poorest to find income opportunities in the informal sector. Another result is that the association between income distribution and poverty is stronger when crises are associated with a fall in income. This fall in income accounts for $15 \%$ to $30 \%$ of the variations in the poverty and inequality indicators. They find no significant impact on formal unemployment. The rise in inflation is associated with an increase in the income share of the middle-income quintile, while fiscal retrenchment is associated with a worsening of the income distribution.

The micro-analysis shows a very different picture. Although they still find a positive impact on poverty, they observe a decrease in inequality, explained by a stronger fall in the incomes of the richest. They find that households that were already poor before the crisis are not necessarily the 
hardest hit. They show that crises are indeed likely to have a massive distributional impact which may be hidden if only the macroeconomic aggregates are examined.

Their empirical analysis has several drawbacks. First, the macroeconomic analysis focuses only on currency crises. The effects of a banking crisis are likely to be very different. Second, the possible influence of other factors is not addressed. Concerning the micro-analysis, the authors acknowledges that the changes observed between 1994 and 1996 can be explained by other factors, the first being adoption of NAFTA which had a strong distributional impact.

Galbraith and Jiaquing (1999) also study the impact of financial crises on inequality and focus on currency crises. They use the dataset from Kaminsky and Reinhart (1999) which defines financial crisis as a weighted average of exchange rate changes and reserve changes. They find that the mean increase in inequality in the two-year period immediately following a crisis is $16.2 \%$, against $3.2 \%$ in years without crises, the difference between the two being statistically significant. However, this analysis does not take account of possible confounding factors that might affect both the probability of a crisis, and inequality. They note also that crises raise inequalities "more in the most deregulated labor markets and less in more highly regulated ones" (Galbraith and Jiaquing, 1999, p. 7). They point out that financial crises have had "worse effects on Latin America workforces than on Asians, and worse on Asians than on the organized and politically powerful workers of the North" (Galbraith and Jiaquing, 1999, p. 7). Although this possible interaction between labor market institutions and the effect of a crisis is interesting, it needs to be confirmed by more systematic empirical studies focusing on the identification of a causal link.

There is another paper on the impact of systemic banking crises on the top income share in the United States. Morelli (2014) shows that these crises had very little impact on the income of the top decile. He identifies three possible theoretical channels and takes into account possible reverse causality (e.g. the impact of inequality on financial crises). The three channels are (1) Stock and Real Estate markets dynamics, (2) the Economic Recession and unemployment, and (3) the effect of government interventions and fiscal policies. He estimates a total short-run effect, taking account of all these possible channels. He uses gross income distribution data in order to exclude the direct effect of changes in fiscal policy. Marginal tax rates at the top are included as additional control variables in order to account for the indirect effects of fiscal policy (e.g. the effect of changes in the tax rate on pre-tax income). Morelli focuses only on systemic banking crises, based on three databases: Bordo et al. (2001), Reinhart and Rogoff (2009b), Laeven and Valencia (2008). During the last century, the Great Depression of the 1930s, the Savings \& Loan crisis of the 1980-1990s, and the Great Recession 
of 2008-2009 are characterized as systemic banking crises. Morelli (2014) uses data for the United States top-income shares built by Piketty and Saez (2003). A first look at the data shows that the impact on the top income share (top $0.01 \%$ and top $10 \%$ ) was low. The stronger negative impact is observed for the Great Depression. Morelli (2014) then conducts several counterfactual analyses that confirm the small impact of such crises on the top income share. Only the post-crisis growth rate for the top $0.01 \%$ tends to be lower than was predicted based on the pre-crisis trend. The author concludes that "the impact of US banking crises so far has been negative at the very top, positive at the bottom of the decile and, as a consequence, neutral for the entire top decile share” (Morelli, 2014, p. 23). These differences can be explained by the composition of income for the different percentiles. It seems that capital income is the main driver of the growth of total income for the richest while wage income appears to be more important for the 90-95\% group. Morelli (2014) argues that these households benefit from relatively higher protection against unemployment and wage cuts compared to the bottom of the distribution. He observes that the rise of this group is observed when changes to unemployment are more pronounced. Concerning the evolution of capital income, he suggests that it may be driven by "endogenous behavioral response of investors to market conditions. (...) Investors might liquidate their risky assets during downsizing and re-purchase assets once the market prospects are improving." (Morelli, 2014, p. 39). Also the high cyclicality of top wage income may explain part of the effect for the top $0.01 \%$. This is consistent with Frydman and Saks (2010) who show the strong correlation between the stock market index and compensation of firm executives.

A second strand in the literature focuses on the impact of financial crises on labor shares. As we have seen, it is likely that the income dynamics differ for capital and labor incomes. In other words, labor and capital income may be affected differently by financial crises. One feature of globalization is that capital is much more mobile than labor. Thus, labor is more likely to bear the largest burden in the case of negative shocks, since capital can always move elsewhere. Using a large panel of countries, Diwan (2001) shows that currency crises are associated with a strong fall in the labor share. This fall is only partially compensated for in the succeeding years. Thus, he argues that the long-term trend of declining labor share is mainly explained by financial crises. Maarek and Orgiazzi (2013) find similar results using a panel of manufacturing sectors in 20 advanced economies. The interesting feature of this research is their exploration of within and across sector effects. By eroding the bargaining power of workers, financial crises may reduce the labor share within sectors. However, it can also lead to structural changes with various effects among sectors. On average, they find that currency crises reduce the labor share by 2 percentage points, and this effect comes mainly from within manufacturing sectors changes. This last result is consistent with Bazillier and Najman (2012) who use a panel of 
developing and developed countries and aggregate data. This paper extends the analysis to banking crises and finds very different results. Although currency crises are found to reduce the labor share by 2 percentage points in the three years following a crisis, banking crises primarily affect capital returns, at least in the year of the crisis. Bazillier and Najman (2012) also find a stronger effect of banking crises in OECD countries, with a more positive impact in the year of the crisis but also with significant fall in the labor share in succeeding years. These results confirm the potential heterogeneity of the impact of financial crises, depending on the type of crisis.

As in Morelli (2014), it is possible to characterize the current crisis as a systemic banking crisis. Therefore, all previous studies focusing on currency crises have little predictive power on the potential impact of such crises; we have seen that the distributional impact is more likely to differ for banking crises. At the cross-country level, the most comprehensive study on the distributional impact of the Great Recession is Jenkins et al. (2013) which focuses on 21 OECD countries. Overall, they find little change in household distribution of income in the two years following the crisis (2007-2009). Over the first years of the crisis, it seems that social protection plays a role in supporting household incomes, resulting in gross household disposable income rising in 12 countries. The most notable case is Ireland where the GDP fell by $11 \%$ while total household income rose by over $3.5 \%$. Building a counterfactual based on social spending prior to the crisis, they find that total household sector incomes would have fallen without government support in the form of the tax and benefits system in most countries. However, they believe that consolidation policies implemented after 2010 are likely to have a greater effect on income distribution.

Meyer and Sullivan (2013) analyze the evolution of income and consumption inequality in the United States over the period 2000-2011. Using the 90/10 ratio as a proxy for inequality, they find that income inequalities rose by $11 \%$ between 2007 and 2011, while consumption inequalities decreased after 2005. During the Great Recession, one explanation is that the fall in asset prices had a strong effect on higher level consumers. This leads to a negative wealth effect that may have a stronger impact on the richest households (De Nardi et al., 2012).

Cho and Newhouse (2013) do not directly study the impact of the crisis on income inequality but indirectly address the issue by studying the impact on different categories of workers using a sample of 17 middle-income countries. Female workers and low-skilled workers are not necessarily the most affected by the crisis. On the contrary, "better educated and urban residents, to a lesser extent, also suffered disproportionate employment losses. The decline in wage employment was also slightly larger 
for more educated workers" (Cho and Newhouse, 2013, p. 37). These results suggest small impact of the crisis on inequality, at least in middle-income countries.

This last result contradicts other studies on emerging countries such as South Africa (Leung et al., 2009) or China (Giles et al., 2012) where low-skilled workers are found to be more affected by the crisis. In the United States, Elsby et al. (2010) find that vulnerable groups, including low-skilled workers, were more affected by the crisis, suggesting a possible positive impact on inequalities. Hoynes et al. (2012, p. 28) find similar results: "the impacts of the Great Recession have been felt most strongly for men, black and Hispanic workers, youth, and low-education workers". They note also that the cyclicality across demographic groups is very similar to previous recessionary periods.

Financial crises may have a direct effect on the distribution of income but also an indirect effect through the effect related to policy responses. In most countries, the crisis has been followed by fiscal consolidation which may have had strong distributional impact. Using a panel of 17 OECD countries over the period 1978-2009, Ball et al. (2013) show that fiscal consolidation is usually associated with a rise in inequality, a fall in the labor share, and a rise in long-term unemployment. This result is confirmed by Woo et al. (2013) for a panel of emerging and advanced economies since the mid 1980s. They find that, on average, fiscal consolidation of 1 percentage point of GDP is associated with an increase in the Gini coefficient of around $0.4 \%-0.7 \%$ over the first two years. As unemployment is found to increase inequalities, and fiscal consolidation increases unemployment, they show that $15 \%$ $20 \%$ of the inequality increase following a fiscal consolidation is explained by the rise in unemployment.

Fiscal consolidation may also have adverse effects on inequality if governments decide to cut social spending. Woo et al. (2013) show that a $1 \%$ decrease in social spending is associated with a rise of $0.2 \%$ to $0.7 \%$ in inequality. Lewis and Verhoeven (2010) show that crises have a strong effect on social spending. Although most governments try to protect investment in education, the lowest income countries are more likely to cut social spending during crises. Bonnet et al. (2010) confirm that the Great Recession was followed by cuts in social security spending.

Overall, the distributional impacts of crises are the subject of debate, and there is no consensus on the sign of the relationship. However, it is clear that there is an impact, and also that a majority of studies conclude about an increase in inequality following a financial crisis. This highlights the need to address seriously the problem of reverse causality when dealing about the causal impact of inequality on leverage and financial crises. 


\section{Conclusion}

In this paper, we surveyed the recent theoretical and empirical literature on the potential linkages between inequalities, leverage, and financial crises. There is strong evidence supporting the idea that inequalities do play a role in the dynamics of credit, finance, and possibly financial crises. The exact extent and direction of the causal relation is more difficult to establish per se, mainly because of the obvious, reverse impact of both finance and financial crises on the distribution of income.

First, inequalities are likely to affect both credit demand and credit supply, directly and indirectly. We have presented a wide range of theoretical studies explaining why households may increase their borrowings in response to rising inequalities, consistent with the dynamics observed in developed countries prior to the Great Recession. An alternative explanation relies on an increase in credit supply related to both an accommodative monetary policy and financial liberalization. Stagnant income in the poorest households (but also the middle-classes more generally) may have pushed central banks and governments to implement policies aimed at supporting aggregate demand through increased borrowings for these households.

On the other hand, one cannot completely discard that the relation between inequalities and the credit boom has been more coincident than causal, since financial deregulation tends to increase inequalities and aims also at directly increasing credit. Banking deregulation and policies promoting the development of finance have been a common economic policy trend in most countries for 30 years. The links between inequalities and leverage are likely to be a mixture of direct and indirect causal relations, as well as coincidental factors. The remaining challenge is to empirically measure the relative weight of each channel.

Second, regarding the other direction of the relationship between inequality and finance, the effects of financial development and financial deregulation on income distribution are not necessarily identical, and are conditioned strongly on the quality of the institutions preventing rent-capturing behaviors. In this regard, there is some emerging evidence that financial deregulation may increase inequality if the growth of the financial sector diverts labor and resources from other fields in the private sector. Overall, the results are very sensitive to the choice of inequality measure and database. Finally, research on the distributional impact of financial crises is very scarce, and there is no emerging consensus on the sign of the relationship.

In summary, there is little doubt that there are links between inequality and leverage, and these are likely to be a mix of direct and indirect causal relations, and coincidental factors. We need to provide 
sound empirical measures of the relative weight of each of these channels. First, at the macro level we need to reassess the empirical relationship between inequalities and leverage. The literature provides contradictory results mainly due to perfectible identification strategies. Because of the two-way relationship between finance and inequality, endogeneity is a major issue, and an adequate empirical treatment requires the identification of relevant instruments.

The second challenge is to determine what measures really matter. Is it the level or the evolution of inequalities that is likely to have an effect on credit? In addition, the choice of a measure for inequality is not neutral. For credit demand, the distribution at the bottom of the income distribution is more likely to matter. For credit supply, it is the distribution at the top. Empirical studies should seek to test the influence of different inequality measures to assess the reliability of their results. The last dimension is the measure for credit. Many studies use the aggregate level of credit which is not consistent with the underlying theoretical background: inequalities are likely primarily to affect household debt. It would also be useful to study the disaggregated impact on different types of household credit.

Third, it would be useful to build on the micro literature on the determinants of credit, based on household microdata. If a rise of inequalities is explained by a permanent income shock, households should adjust their consumption accordingly. Work that finds differences between income inequality and consumption inequality show that this does not happen. It would be interesting to identify whether this behavior is explained by the "keeping up with the Joneses" phenomenon or by more basic expectations errors.

Finally, more research is need on the impact of the Great Recession and the fiscal consolidation policies that followed. More generally, more systematic analyses of the possible distributional trends occurring after a financial crisis are needed: from the existing studies it appears that these effects are very heterogeneous across the different type of crises, pointing to different channels of transmissions which require more precise identification.

The topic of finance and inequality is attracting growing interest. The various intertwined, complex mechanisms surveyed in this paper need some additional investigation to precisely gauge the direction of causalities, and the relative importance of each channel. These circular dynamics may have substantial implications for emerging countries, since an increasing number face a joint increase in inequality and credit. We believe that this provides promising paths for future research. 


\section{References}

Acemoglu, D. (2011), “Thoughts on inequality and the financial crisis", AEA meeting, Denver.

Aghion, P., Bolton, P. (1992), "Distribution and growth in models of imperfect capital markets", European Economic Review 36, 603-611.

Aghion, P., Bolton, P. (1997), "A theory of trickle-down growth and development", Review of Economic Studies 64, 151-172.

Aizenman, J. and Jinjarak, Y. (2012), "Income Inequality, Tax Base and Sovereign Spreads", FinanzArchiv: Public Finance Analysis, Mohr Siebeck, Tübingen, vol. 68(4), pages 431-444, December.

Alvaredo, F., Atkinson, A.B., Piketty, T. and Saez, E. (2014), The World Top Incomes Database, http://topincomes.g-mond.parisschoolofeconomics.eu/, 20/02/2015.

Alvarez-Cuadrado, F. and El-Attar, M. (2012), "Income Inequality and Saving", IZA Discussion Papers 7083, Institute for the Study of Labor (IZA).

Al-Hussami, F. and Martín Remesal, A. (2012), "Current Account Imbalances and Income Inequality: Theory and Evidence", Kiel Advanced Studies Working Papers 459, Kiel Institute for the World Economy.

Ang, J.B. (2010), "Finance and Inequality: The Case of India," Southern Economic Journal 76(3), pages $738-761$

Arora, R.U. (2012), "Finance and inequality: a study of Indian states", Applied Economics 44, 4527 4538 ,

Atkinson, A.B. (1997), "Bringing Income Distribution in from the Cold", Economic Journal, vol. 107(441), pp. 297-321.

Atkinson, A.B and Morelli, S. (2010), "Income Inequality and Banking Crisis : a First look", Report prepared for the Global Labor Forum 2011 (ILO), Turin.

Atkinson, A.B and Morelli, S. (2011), "Economic crises and Inequality", Human Development Research Papers (2009 to present) HDRP-2011-06, Human Development Report Office (HDRO), United Nations Development Programme (UNDP).

Atkinson, A.B., Piketty, T. \& E. Saez (2011), “Top Income in the Long Run History”, Journal of Economic Literature, 49(1): 3-71.

Aziz, J., Caramazza, F. and Salgado, S. (2000). "Currency Crises: In Search of Common Elements." IMF Working Paper WP/00/67, International Monetary Fund. 
Azzimonti, M., de Francisco, E. and Quadrini, V. (2014), "Financial Globalization, Inequality, and the Rising Public Debt", American Economic Review, 104(8): 2267-2302.

Baker, M., Nagel, S. and Wurgler, J. (2007), “The Effect of Dividends on Consumption”, Brookings Papers on Economic Activity, Economic Studies Program, The Brookings Institution, vol. 38(1), pages 231-292.

Baldacci, E., de Mello, L. and Inchauste, G. (2002), "Financial Crises, Poverty and Income Distribution”, IMF Working Paper WP/02/4

Ball, L., Furceri, D., Leigh, D. and Loungani, P. (2013), "The Distributional Effects of Fiscal Consolidation,” IMF Working Paper 13/151 (Washington: International Monetary Fund)

Banerjee, A.V. and Newman, A.F. (1993), "Occupational Choice and the Process of Development," Journal of Political Economy, University of Chicago Press, vol. 101(2), pages 274-98, April.

Bazillier, R. and Najman, B. (2012), "Labor and Financial Crises: Is Labor paying the price of the crisis?", mimeo.

Beck, T., Demirgüç-Kunt, A. and Levine, R. (2000), "A New Database on Financial Development and Structure," World Bank Economic Review 14, 597-605.

Beck, T., Demirguc-Kunt, A. and Levine, R. (2007), "Finance, Inequality, and the Poor”, Journal of Economic Growth Vol. 12(1), pages 27-49.

Beck, T., Demirgüç-Kunt, A. and Levine, R. (2009), "Financial Institutions and Markets Across Countries and over Time: Data and Analysis", World Bank Policy Research Working Paper 4943, May 2009.

Beck, T., Levine, R., and Levkov, A. (2010), "Big Bad Banks? The Winners and Losers from US Branch Deregulation", Journal of Finance 65(5), pages 1637-1667.

Behringer, J. and van Treeck, T. (2013), "Income distribution and current account: A sectoral perspective", IMK Working Paper 125-2013, IMK at the Hans Boeckler Foundation, Macroeconomic Policy Institute.

Belabed, C.A., Theobald, T. and van Treeck, T. (2013), "Income Distribution and Current Account Imbalances", IMK Working Paper 126-2013, IMK at the Hans Boeckler Foundation, Macroeconomic Policy Institute.

Bellettini, G. and Delbono, F. (2013), "Persistence of high income inequality and banking crises: 1980-2010", Working Papers wp885, Dipartimento Scienze Economiche, Universita' di Bologna. 
Berg, A. and Pattillo, C. (1999), "Predicting currency crises: The indicators approach and an alternative", Journal of International Money and Finance, Elsevier, Elsevier, vol. 18(4), pages 561-586, August.

Bertrand, M. and Morse, A. (2013), “Trickle-down Consumption,” NBER Working Paper No. 18883.

Bonnet, F., Ehmke, E. and Hagemejer, K. (2010), "Social Security in Times of Crisis" International Social Security Review, Vol. 63, Issue 2, pp. 47-70, April/June 2010.

Bordo, M.D., Eichengreen, B., Klingebiel, D. and Martinez-Peria, M.S. (2001), "Is the crisis problem growing more severe?”, Economic Policy, CEPR;CES;MSH, CEPR;CES;MSH, vol. 16(32), pages 51-82, 04 .

Bordo, M.D., and Meissner, C.M. (2012), "Does inequality lead to a financial crisis?", Journal of International Money and Finance, Elsevier, vol. 31(8), pages 2147-2161.

Bourguignon, F. (2004). "The Poverty-growth-inequality triangle", New Delhi Working Papers, Indian Council for Research on International Economic Relations, New Delhi, India 125

Buyukkarabacak, B. and Valev, N. (2010), "Credit Expansions and Banking Crises: The role of household and enterprise credit,", Journal of Banking and Finance, 34(6), 1247-1256

Christen, M. and Morgan, R. (2005), "Keeping Up With the Joneses: Analyzing the Effect of Income Inequality on Consumer Borrowing”, Quantitative Marketing and Economics, Springer, vol. 3(2), pages 145-173.

Cho, Y. and Newhouse, D. (2013), “"How Did the Great Recession Affect Different Types of Workers? Evidence from 17 Middle-Income Countries," World Development, Elsevier, vol. 41(C), pages 31-50.

Čihák, M., Demirgüç-Kunt, A., Feyen, E. and Levine, R. (2012) "Benchmarking Financial Development Around the World”, World Bank Policy Research Working Paper 6175, August 2012.

Claessens, S. and Perotti, E. (2007), "Finance and inequality: Channels and evidence", Journal of Comparative Economics 35(4), pages 748-773.

Clarke, G.R.G., Xu, L.C. and Zou, H.F. (2006), "Finance and Income Inequality: What Do the Data Tell Us?", Southern Economic Journal, 72(3), pages 578-596,

Coibion, O., Gorodnichenko, Y., Kueng, L. and Silvia, J. (2012), “Innocent Bystanders? Monetary Policy and Inequality in the U.S”, NBER Working Papers 18170, National Bureau of Economic Research, Inc. 
Coibion, O., Gorodnichenko, Y, Kudlyak, M. and Mondragon, J. (2014), "Does Greater Inequality Lead to More Household Borrowing? New Evidence from Household Data", NBER Working Papers 19850, National Bureau of Economic Research, Inc.

Demetriades, P.O. and Luintel, K.B. (1996), "Financial Development, Economic Growth and Banker Sector Controls: Evidence from India," Economic Journal, Royal Economic Society, vol. 106(435), pages 359-74, March.

Demetriades, P.O. and Luintel, K.B. (1997), "The Direct Costs Of Financial Repression: Evidence From India," The Review of Economics and Statistics, MIT Press, vol. 79(2), pages 311-320, May.

De Nardi, M-C., French, E. and Benson, D. (2012), "Consumption and the Great Recession" Economic Perspectives, Federal Reserve Bank of Chicago, Federal Reserve Bank of Chicago, issue Q I, pages 1-16.

Diwan, I. (2001), "Debt as sweat: labor, financial crises, and the globalization of capital", The World Bank, mimeo, July.

Duesenberry, L.SL. (1949), Income, Saving and the Theory of Consumer Behavior, Cambridge: Harvard University Press

Eichengreen, B. and Mitchener, K.J. (2003), "The Great Depression as a Credit Boom Gone Wrong”, Bank for International Settlements Working Paper 137.

Elsby, M.W.L., Hobijn, B. and Sahin, A. (2010), "The Labor Market in the Great Recession", Brookings Papers on Economic Activity, Economic Studies Program, The Brookings Institution, vol. 41(1 (Spring), pages 1-69.

Enowbi Batuo, M., Guidi, F., Mlambo, K. (2010), "Financial Development and Income Inequality: Evidence from African Countries" MPRA Paper 25658, University Library of Munich,

Fisher, I. (1932), Booms and Depressions. New York: Adelphi.

Fisher, I. (1933), “The Debt-Deflation Theory of Great Depressions”, Econometrica, pp.337-57

Frank, R.H., Levine, A.S. and Dijk, O. (2014), "Expenditure Cascades", Review of Behavioral Economics, now publishers, vol. 1(1-2), pages 55-73, January.

Frankel, J.A. and Rose, A.J. (1996) "Currency Crashes in Emerging Markets: Empirical Indicators", NBER Working Papers 5437, National Bureau of Economic Research, Inc.

Frydman, C. and Saks, R.E. (2010), "Executive Compensation: a new view from a long-term perspectives, 1936-2005”, Review of Financial Studies, 23(5), 2099- 
Galbraith, J K. (1954), The Great Crash, 1929, Houghton Mifflin, New York.

Galbraith, J.K. and L. Jiaqing (1999), “Inequality and Financial Crises: Some Early Findings”, UTIP Working Paper $\mathrm{N}^{\circ}$.

Galor, O. and Zeira, J. (1993), "Income Distributions and Macroeconomics", Review of Economic Studies, 60,35-52.

Giles, J., Park, A., Fang, C., \& Du, Y. (2012), "Weathering a storm: Surveybased perspectives on employment in China in the aftermath of the financial crisis". World Bank Policy Research Paper 5984.

Gimet, C., Lagoarde-Segot, T. (2011), "A closer look at financial development and income distribution", Journal of Banking \& Finance 35(7), pages 1698-1713,

Goldstein, M., Kaminsky, G. and Reinhart, C. (2000), "Assessing financial vulnerability, an early warning system for emerging markets: Introduction”, MPRA Paper 13629, University Library of Munich, Germany.

Gornemann, N., Kuester, K. and Nakajima, M. (2014), "Doves for the Rich, Hawks for the Poor? Distributional Consequences of Monetary Policy", mimeo.

Gourinchas, P.-O., Valdes, R. and Landerretche, O. (2001), "Lending Booms: Latin America and the World." Economia: Journal of the Latin American and Caribbean Economic Association 1(2): 47-89.

Greenwood, J. and Jovanovic, B. (1990), "Financial Development, Growth and the distribution of income", Journal of Political Economy 98(5):1076-107.

Greenwood, R., Scharfstein, D. (2013), "The Growth of Finance", Journal of Economic Perspectives, American Economic Association, vol. 27(2), pages 3-28, Spring.

Gupta, P., Mishra, D. \& Sahay, R. (2007), "Behavior of output during currency crises”, Journal of International Economics, Elsevier, Elsevier, vol. 72(2), pages 428-450, July.

Hoynes, H., Miller, D.M and Schaller, J. (2012), "Who Suffers during Recessions?," Journal of Economic Perspectives, American Economic Association, vol. 26(3), pages 27-48, Summer.

Hume, M. and Sentance, A. (2009), "The Global Credit Boom: Challenges for Macroeconomics and Policy”. Bank of England External MPC Unit Discussion Paper 27.

Hutchison, M. and McDill, K. (1999), “Are All Banking Crises Alike? The Japanese Experience in International Comparison", Journal of the Japanese and International Economies, Elsevier, vol. 13(3), pages 155-180, September. 
Hutchison, M. and Noy, I. (2002), "Output Costs of Currency and Balance of Payments Crises in Emerging Markets", Comparative Economic Studies, Palgrave Macmillan, Palgrave Macmillan, vol. 44(2-3), pages 27-44, September.

Hutchison, M. and Noy, I. (2005), "How Bad Are Twins? Output Costs of Currency and Banking Crises", Journal of Money, Credit and Banking, Blackwell Publishing, Blackwell Publishing, vol. 37(4), pages 725-52, August.

Iacoviello, M. (2008), "Household Debt and Income Inequality, 1963-2003”, Journal of Money, Credit and Banking, Blackwell Publishing, vol. 40(5), pages 929-965, 08.

Jauch, S. and Watzka, S. 2011. "Financial Development and Income Inequality: A Panel Data Approach”, CESifo Working Paper Series 3687, CESifo Group Munich.

Jenkins, S.P., Brandolini, A., Micklewright, J. and Nolan, B. (2013), The Great Recession and the Distribution of Household Income, Oxford : Oxford University Press.

Jordà, O., Schularick, M. and Taylor, A.M. (2011), "Financial Crises, Credit Booms, and External Imbalances: 140 Years of Lessons”, IMF Economic Review, vol. 59(2), pages 340-378

Jordà, O., Schularick, M. and Taylor, A.M. (2013a), "When Credit Bites Back," Journal of Money, Credit and Banking, vol. 45(s2), pages 3-28.

Jordà, O., Schularick, M. and Taylor, A.M. (2013b), "Sovereigns versus Banks: Credit, Crises, and Consequences," NBER Working Papers 19506, National Bureau of Economic Research, Inc.

Kalecki, M. (1954), Theory of Economic Dynamics: An Essay on Cyclical and Long-RunChanges in Capitalist Economy., George Allen, Unlisted.

Kaminsky, G.L. and Reinhart. C.M. (1999), "The Twin Crises: The Causes of Banking and Balanceof-Payments Problems", American Economic Review 89(3): 473-500.

Kappel, V. (2010). "The Effects of Financial Development on Income Inequality and Poverty", Working Paper 10-127, Center of Economic Research at ETH Zurich,

Kim, D-H. and Lin, S-C. (2011), "Non-linearity in the financial development and "income inequality nexus", Journal of Comparative Economics 39(3), pages 310-325.

Kopczuk, W., Saez, E. and Song, J. (2010), "Earnings Inequality and Mobility in the United States: Evidence from Social Security Data since 1937”, The Quarterly Journal of Economics, MIT Press, vol. 125(1), pages 91-128, February.

Krueger, D. and Perri, F. (2006), "Does Income Inequality Lead to Consumption Inequality? Evidence and Theory", Review of Economic Studies, vol. 73(1), pages 163-193. 
Krueger, D. and Perri, F. (2011), "How does Household Consumption Respond to Income Shocks?", mimeo. Available online: http://economics.sas.upenn.edu/ dkrueger/research/Shocks.pdf

Krugman, P. (2010), "Inequality and Crises", New York Times blog "The Conscience of a liberal", (June), http://krugman.blogs.nytimes.com/2010/06/28/inequality-and-crises/

Kumhof, M., Ranciere, R. and Winant, P. (2015), "Inequality, Leverage and Crises: The Case of Endogenous Default", American Economic Review, forthcoming.

Kumhof, M., Lebarz, C., Ranciere, R., Richter, A.W, and Throckmorton, N.A. (2012), "Income Inequality and Current Account Imbalances", IMF Working Papers 12/8, International Monetary Fund.

Laeven, L. and Valencia, F. (2008) "Systemic Banking Crises; A New Database," IMF Working Papers 08/224, International Monetary Fund.

Law, S.H. and Tan, H.B. (2009), "The Role Of Financial Development On Income Inequality In Malaysia”, Journal of Economic Development 34(2), pages 153-168.

Law, S.H. and Tan, H.B. (2012), "Nonlinear dynamics of the finance-inequality nexus in developing countries", Journal of Economic Inequality 10(4), pages 551-563,

Leigh, A. and Posso, A. (2009), “Top Incomes And National Savings”, Review of Income and Wealth, International Association for Research in Income and Wealth, vol. 55(1), pages 57-74, 03.

Leung, R., Stampini, M., \& Vencatachellum, D. (2009). Does human capital protect workers against exogenous shocks? South Africa in the 2008-2009 crisis. IZA Working Paper No. 4608.

Levine, R. (2005), "Finance and growth: theory and evidence", in P. Aghion and S. Durlauf (eds.), Handbook of Economic Growth, Amsterdam: North-Holland, pp. 866-934.

Lewis, M. and Verhoeven, M. (2010), "Financial Crises and Social Spending : The Impact of the 2008-2009 Crisis”, World Bank Other Operational Studies 12965, The World Bank.

Lysandrou, P. (2011), "Global Inequality, Wealth Concentration and the Subprime Crisis: A Marxian Commodity Theory Analysis", Development and Change, Vol. 42(1), pages 183-208.

Maarek, P. and Orgiazzi, E. (2013), "Currency Crises and the Labor Share”, Economica vol. 80 (319), pages $566-588$.

Martin, P. and Phillippon, T. (2014), "Inspecting the Mechanism: Leverage and the Great Recession in the Eurozone", National Bureau of Economic Research Working Paper \#20572.

McKinnon, R. and Pill H. (1997) "Credible Economic Liberalizations and Overborrowing”, American Economic Review 87(2), 189-93. 
Milesi-Ferretti, G.M. and Razin, A. (2000), "Current Account Reversals and Currency Crises: Empirical Regularities", NBER Chapters, National Bureau of Economic Research, Inc ,in: Currency Crises, pages 285-323. National Bureau of Economic Research, Inc.

Mendoza, E.G. and Terrones, M.E. (2008), “An Anatomy Of Credit Booms: Evidence From Macro Aggregates And Micro Data", NBER Working Papers 14049.

Meyer, B.D., and Sullivan, J.X. (2013), "Consumption and Income Inequality and the Great Recession", American Economic Review, 103(3): 178-83.

Mian, A. and Sufi, A. (2010), "Household Leverage and the Recession of 2007-09". IMF Economic Review 58(1): 74-117.

Milasi, S. (2012), “Top Income Shares and Budget Deficits”, CEIS Research Paper 249, Tor Vergata University, CEIS, revised 08 Aug 2013.

Minsky, H.P. (1977), “The Financial Instability Hypothesis: An Interpretation of Keynes and an Alternative to 'Standard' Theory”. Nebraska Journal of Economics and Business 16(1): 5-16.

Moffitt, R.A. and Gottschalk, P. (2002), "Trends in the Transitory Variance of Earnings in the United States", Economic Journal, Royal Economic Society, vol. 112(478), pages C68-C73, March.

Moffitt, R.A. and Gottschalk, P. (2011). "Trends in the covariance structure of earnings in the U.S.: 1969-1987," Journal of Economic Inequality, Springer, vol. 9(3), pages 439-459, September.

Morelli, S. (2014), "Banking Crises in the US: the Response of Top Income Shares in a Historical Perspective," CSEF Working Papers 359, Centre for Studies in Economics and Finance (CSEF), University of Naples, Italy.

Mookerjee, R. and Kalipioni, P. (2010), "Availability of financial services and income inequality: The evidence from many countries", Emerging Markets Review 11(4), pages 404-408.

Perugini, C., Hölscher, J. and Collie, S. (2015), “Inequality, Credit and Financial Crises”, Cambridge Journal of Economics, forthcoming.

Philippon, T. and Reshef, A. (2012), "Wages and Human Capital in the US Finance Industry: 19092006, vol. 127, no.4, 1551-1609.

Piketty, T. (1997), "The dynamics of wealth distribution and the interest rate with credit rationing", Review of Economic Studies 64, 173-189.

Piketty, T. (2003), "Income Inequality in France, 1901-1998”, Journal of Political Economy, vol. 111, n`5, 2003, pp. 1004-1042.

Piketty, T. (2014), “Capital in the 21st Century”, Cambridge: Harvard University Press. 
Piketty, T. and Saez, E. (2003), "Income Inequality in the United States, 1913-1998", Quarterly Journal of Economics, vol. 118, no. 1, 1-39.

Piketty, T. and Saez, E. (2006), "The evolution of top incomes: a historical and international perspectives", American economic review, vol.96, no 2, 2006, p. 200-205.

Piketty, T. and Saez, E. (2013), “Top Incomes and the Great Recession: Recent Evolutions and Policy Implications", IMF Economic Review, Palgrave Macmillan, vol. 61(3), pages 456-478, August.

Rajan, R.G. (2010), Fault lines: How hidden fractures still threaten the world economy, Princeton University Press, Princeton.

Reinhart, C.M., and Rogoff. K.S. (2009), This Time Is Different: Eight Centuries of Financial Folly. Princeton, NJ: Princeton University Press.

Reinhart, C.M., and Rogoff. K.S. (2009b), "The Aftermath of Financial Crises", American Economic Review, American Economic Association, American Economic Association, vol. 99(2), pages 466-72, May.

Reinhart, C.M., and Rogoff. K.S. (2010), "Growth in a Time of Debt", American Economic Review, vol. 100(2), pages 573-78.

Romer, C.D. and Romer, D.H. (1998), "Monetary Policy and the Well-Being of the Poor", in Income Inequality: Issues and Policy Options (Federal Reserve Bank of Kansas City), 159-201.

Sabelhaus, J. and Song, J. (2009), "Earnings Volatility Across Groups and Time”, National Tax Journal, National Tax Association, vol. 62(2), pages 347-64.

Schmidt-Hebbel, K. and Serven, L. (2000), “Does income inequality raise aggregate saving?”, Journal of Development Economics, Elsevier, vol. 61(2), pages 417-446, April.

Schularick, M. and Taylor, A.M. (2012), "Credit Booms Gone Bust: Monetary Policy, Leverage Cycles, and Financial Crises, 1870-2008," American Economic Review, American Economic Association, vol. 102(2), pages 1029-61, April.

Shleifer, A. \& Vishny, R.W. (2010), "Unstable banking”, Journal of Financial Economics, Elsevier, vol. 97(3), pages 306-318, September.

Solt, F. (2009), "Standardizing the World Income Inequality Database". Social Science Quarterly 90(2), 231-242.

Stiglitz, J. (2009), "Joseph Stiglitz and Why Inequality is at the Root of the Recession", Next Left website. January 92009. 
Tridico, P. (2012), "Financial crisis and global imbalances: its labor market origins and the aftermath", Cambridge Journal of Economics, Oxford University Press, vol. 36(1), pages 17-42.

Veblen, T.B. (1899), "The theory of the leisure class. An economic study in the evolution of institutions”. New York, N.Y. / London: Macmillan / Macmillan 1899, viii, 400 S.

van Treeck, T. (2014), "Did Inequality cause the U.S. Financial Crisis?", Journal of Economic Surveys, vol. 28(3), pages 421-448.

Woo, J., Bova, E., Kinda, T., and Zhang Y. S. (2013), "Distributional Effects of Fiscal Consolidation and the Role of Fiscal Policy: What Do the Data Say?" IMF Working Paper 13/195 (Washington: International Monetary Fund, September). 